Prepared in cooperation with the Forest County Potawatomi Community

\title{
Simulation of the Shallow Groundwater-Flow System in the Forest County Potawatomi Community, Forest County, Wisconsin
}

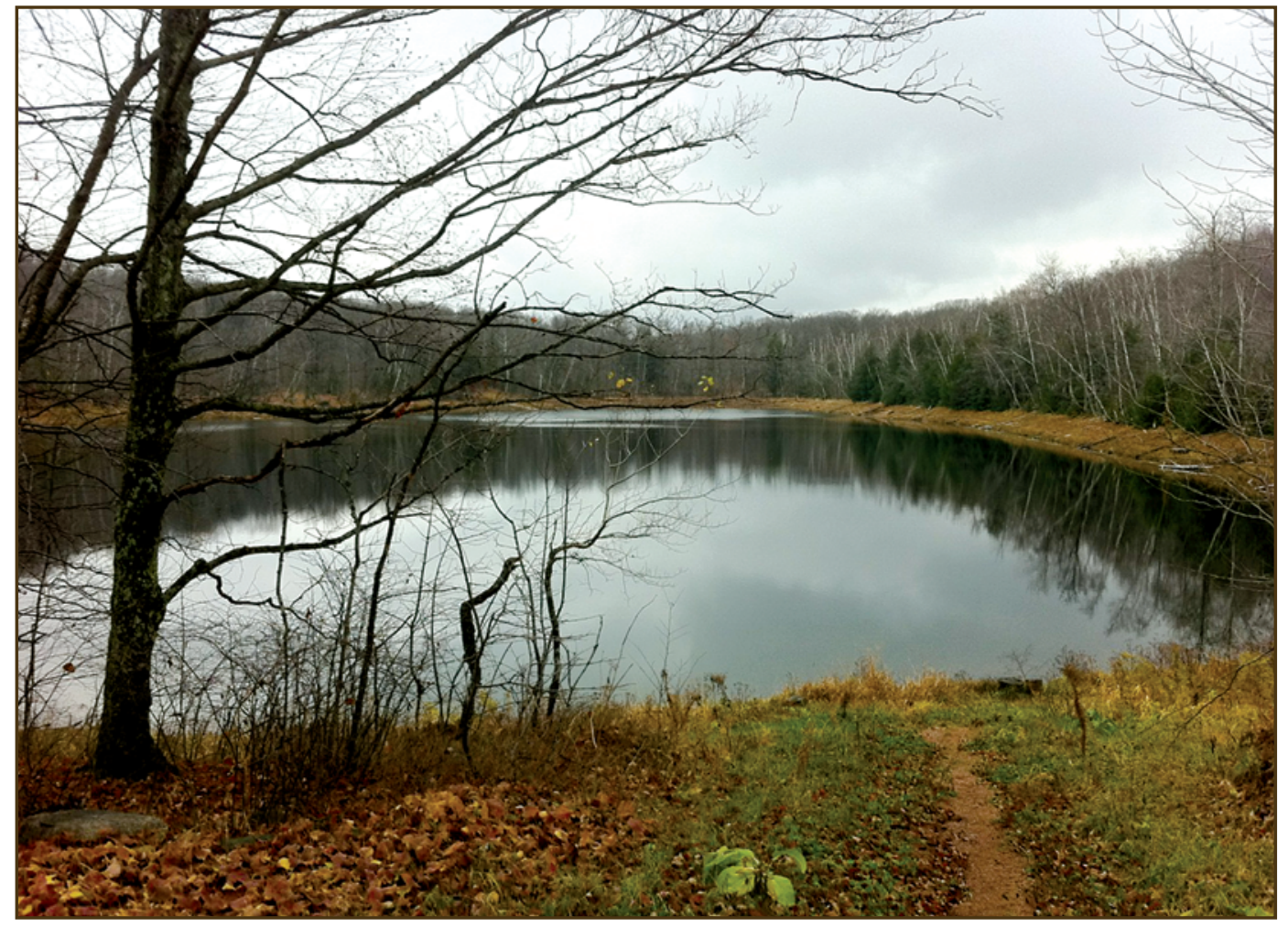

Scientific Investigations Report 2012-5289

U.S. Department of the Interior

U.S. Geological Survey

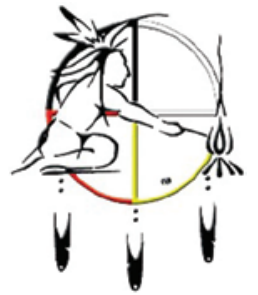


Cover. Bug Lake, Forest County, Wisconsin. (Photograph taken by Michael N. Fienen, U.S. Geological Survey.) 


\section{Simulation of the Shallow Groundwater- Flow System in the Forest County Potawatomi Community, Forest County, Wisconsin}

By Michael N. Fienen, David A. Saad, and Paul F. Juckem

Prepared in cooperation with the Forest County Potawatomi Community

Scientific Investigations Report 2012-5289 


\title{
U.S. Department of the Interior \\ KEN SALAZAR, Secretary
}

\section{U.S. Geological Survey \\ Suzette M. Kimball, Acting Director}

\author{
U.S. Geological Survey, Reston, Virginia: 2013
}

For more information on the USGS - the Federal source for science about the Earth, its natural and living resources, natural hazards, and the environment, visit http://www.usgs.gov or call 1-888-ASK-USGS.

For an overview of USGS information products, including maps, imagery, and publications, visit http://www.usgs.gov/pubprod

To order this and other USGS information products, visit http://store.usgs.gov

Any use of trade, firm, or product names is for descriptive purposes only and does not imply endorsement by the U.S. Government.

Although this information product, for the most part, is in the public domain, it also may contain copyrighted materials as noted in the text. Permission to reproduce copyrighted items must be secured from the copyright owner.

Suggested citation:

Fienen, M.N., Saad, D.A., and Juckem, P.F., 2013, Simulation of the shallow groundwater-flow system in the Forest County Potawatomi Community, Forest County, Wisconsin: U.S. Geological Survey Scientific Investigations Report 2012-5289, 24 p. 


\section{Contents}

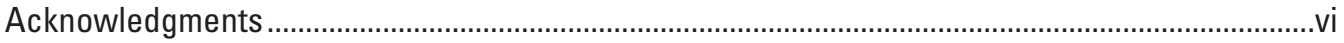

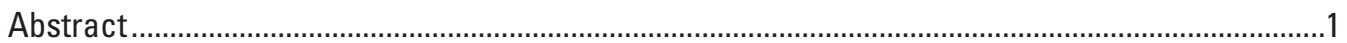

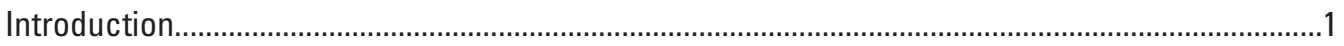

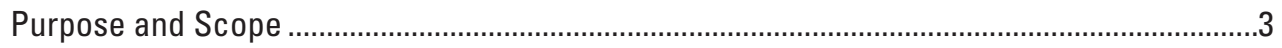

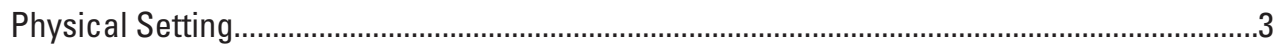

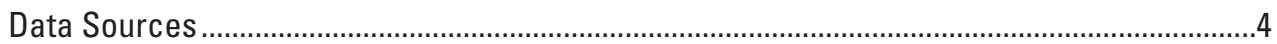

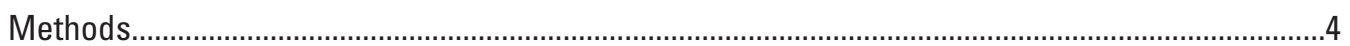

Development of a Conceptual Model of the Shallow Groundwater-Flow System ...................5

Description of the Regional GFLOW Model..........................................................................5

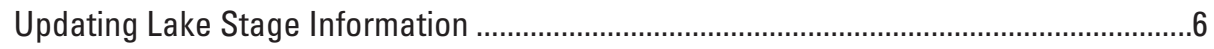

Partial Recalibration using PEST ..............................................................................

Simulation of the Shallow Groundwater-Flow System to Assess Areas Contributing Recharge

to Existing and Proposed Wells in the Forest County Potawatomi Community .....................7

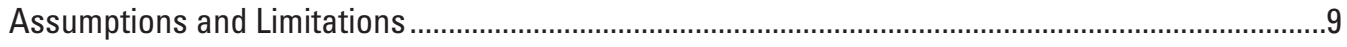

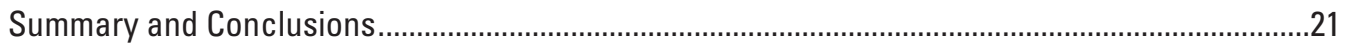

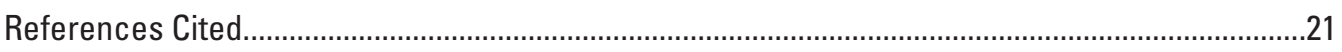

\section{Figures}

1. Map showing location of study area in the Forest County Potawatomi Community, Forest County, Wisconsin, and overview of major model elements (modified and expanded from Fienen and others, 2011) ......................................................................2

2. Chart showing measured and modeled results for streamflow targets before and after partial recalibration of the GFLOW model by using PEST

3. Map showing simulated areas contributing recharge using the GFLOW model for average pumping conditions (North well, 89 gallons per minute; South well, 70 gallons per minute) at Bug Lake Road, Forest County Potawatomi Community, Forest County, Wisconsin.

4. Map showing simulated areas contributing recharge using the GFLOW model for maximum pumping conditions (North well, 150 gallons per minute; South well, 80 gallons per minute) at Bug Lake Road, Forest County Potawatomi Community, Forest County, Wisconsin.

5. Map showing simulated areas contributing recharge using the GFLOW model for average pumping conditions ( 25 gallons per minute from each well) at Lois Crow Drive, Forest County Potawatomi Community, Forest County, Wisconsin..

6. Map showing simulated areas contributing recharge using the GFLOW model for maximum pumping conditions (30 gallons per minute from each well) at Lois Crow Drive, Forest County Potawatomi Community, Forest County, Wisconsin.. 
7. Map showing simulated areas contributing recharge using the GFLOW model for average pumping conditions (North well, 11 gallons per minute; South well, 34 gallons per minute) at Devils Lake Lane, Forest County Potawatomi Community, Forest County, Wisconsin.

8. Map showing simulated areas contributing recharge using the GFLOW model for maximum pumping conditions (North well, 17 gallons per minute; South well, 40 gallons per minute) at Devils Lake Lane, Forest County Potawatomi Community, Forest County, Wisconsin.

9. Map showing simulated areas contributing recharge using the GFLOW model for average pumping conditions ( 60 gallons per minute from each well) at the town of Blackwell, Forest County Potawatomi Community, Forest County, Wisconsin

10. Map showing simulated areas contributing recharge using the GFLOW model for average pumping conditions (North well, 60 gallons per minute; South well, 88 gallons per minute) at the town of Carter, Forest County Potawatomi Community,

Forest County, Wisconsin

11. Map showing simulated areas contributing recharge using the GFLOW model for maximum pumping conditions (North well, 105 gallons per minute; South well, 88 gallons per minute) at the town of Carter, Forest County Potawatomi Community,

Forest County, Wisconsin.

12. Map showing simulated areas contributing recharge using the GFLOW model for average pumping conditions with an additional proposed well (additional North well, 80 gallons per minute; North well, 60 gallons per minute; South well, 88 gallons per minute) at the town of Carter, Forest County Potawatomi Community, Forest County, Wisconsin.

13. Map showing simulated areas contributing recharge using the GFLOW model for maximum pumping with an additional proposed well (additional North well, 100 gallons per minute; North well, 105 gallons per minute; South well, 88 gallons per minute) at the town of Carter, Forest County Potawatomi Community, Forest County, Wisconsin.

1-1. Map showing location of study area near Mole Lake, Forest County, Wisconsin, and overview of major model elements (reproduced from Fienen and others, 2011; modified from Kelson and others, 2002)

\section{Tables}

1. Lake-level measurements (NAVD 88) made during October 25-27, 2010, in the Forest County Potawatomi Community, Forest County, Wisconsin.

2. Flow measurements $\left(\mathrm{O}_{80}\right)$ defined as the flow that is equaled or exceeded 80 percent of the time, provided by the Forest County Potawatomi Community, Forest County, Wisconsin, and used as model-calibration targets.

3. Existing and proposed wells with both average and maximum flow rates, provided by the Forest County Potawatomi Community, Forest County, Wisconsin 


\section{Conversion Factors, Datums, Abbreviated Water-Quality Units, and Abbreviations}

\begin{tabular}{lcl}
\hline \multicolumn{1}{c}{ Multiply } & By & \multicolumn{1}{c}{ To obtain } \\
\hline inch (in.) & Length & centimeter $(\mathrm{cm})$ \\
foot (ft) & 2.54 & meter $(\mathrm{m})$ \\
\hline \multicolumn{3}{c}{ Area } \\
\hline square mile $\left(\mathrm{mi}^{2}\right)$ & 0.3048 & hectare $(\mathrm{ha})$ \\
\hline & 259.0 & \\
\hline cubic foot per day $(\mathrm{ft} / \mathrm{d})$ & Flow rate & cubic meter per day $\left(\mathrm{m}^{3} / \mathrm{d}\right)$ \\
gallon per minute $(\mathrm{gal} / \mathrm{min})$ & 0.02832 & liter per second $(\mathrm{L} / \mathrm{s})$ \\
inch per year (in/yr) & 0.06309 & millimeter per year $(\mathrm{mm} / \mathrm{yr})$ \\
\hline & 25.4 & meter per day $(\mathrm{m} / \mathrm{d})$ \\
\hline foot per day $(\mathrm{ft} / \mathrm{d})$ & Hydraulic conductivity* & \\
\hline
\end{tabular}

Vertical coordinate information is referenced to the North American Vertical Datum of 1988 (NAVD 88).

Horizontal coordinate information is referenced to the North American Datum of 1983, or NAD 83, and the datum as adjusted via the Wisconsin High Accuracy Reference Network (HARN) survey of 1997, or NAD 83 (1997).

Elevation, as used in this report, refers to distance above the vertical datum.

*Hydraulic conductivity: The standard unit for hydraulic conductivity is cubic foot per day per square foot of aquifer cross-sectional area $\left[\left(\mathrm{ft}^{3} / \mathrm{d}\right) / \mathrm{ft}^{2}\right]$. In this report, the mathematically reduced form, foot per day ( $\mathrm{ft} / \mathrm{d})$, is used for convenience.

\section{Abbreviations used in this report:}

AEM analytic element method

FCPC Forest County Potawatomi Community

GPS global-positioning system

RTK real-time kinematic

USGS U.S. Geological Survey 


\section{Acknowledgments}

The authors acknowledge Nate Guldan of the Forest County Potawatomi Community, Natural Resources Department for originating and supporting this study. The authors also acknowledge Michael Parsen of the Wisconsin State Geological and Natural History Survey and Maksym

Gusyev of the Geological and Nuclear Sciences (GNS Science), New Zealand, for their technical review comments, which improved the technical accuracy and readability of this report. 


\title{
Simulation of the Shallow Groundwater-Flow System in the Forest County Potawatomi Community, Forest County, Wisconsin
}

\author{
By Michael N. Fienen, David A. Saad, and Paul F. Juckem
}

\section{Abstract}

The shallow groundwater system in the Forest County Potawatomi Comminity, Forest County, Wisconsin, was simulated by expanding and recalibrating a previously calibrated regional model. The existing model was updated using newly collected water-level measurements, inclusion of surfacewater features beyond the previous near-field boundary, and refinements to surface-water features. The updated model then was used to calculate the area contributing recharge for seven existing and three proposed pumping locations on lands of the Forest County Potawatomi Community. The existing wells were the subject of a 2004 source-water evaluation in which areas contributing recharge were calculated using the fixed-radius method. The motivation for the present (2012) project was to improve the level of detail of areas contributing recharge for the existing wells and to provide similar analysis for the proposed wells.

Delineated 5- and 10-year areas contributing recharge for existing and proposed wells extend from the areas of pumping to delineate the area at the surface contributing recharge to the wells. Steady-state pumping was simulated for two scenarios: a base-pumping scenario using pumping rates that reflect what the Community currently (2012) pumps (or plans to in the case of proposed wells), and a high-pumping scenario in which the rate was set to the maximum expected from wells installed in this area, according to the Forest County Potawatomi Community Natural Resources Department. In general, the 10-year areas contributing recharge did not intersect surface-water bodies. The 5- and 10-year areas contributing recharge simulated at the maximum pumping rate at Bug Lake Road may intersect Bug Lake. At the casino near the Town of Carter, Wisconsin, the 10-year areas contributing recharge intersect infiltration ponds. At the Devils Lake and Lois Crow Drive wells, areas contributing recharge are near cultural features, including residences.

\section{Introduction}

A new groundwater-pumping regime has been proposed by the Forest County Potawatomi Community (FCPC), which includes ongoing pumping from seven existing wells and additional pumping from three proposed wells at five locations in the Forest County Potawatomi Community, Forest County, Wisconsin (fig. 1). A study was performed by the U.S. Geological Survey (USGS), in cooperation with the FCPC, to delineate the area contributing recharge of each of the wells in the proposed pumping regime. The area contributing recharge is the two-dimensional projection, or footprint on the land surface, of the water entering the aquifer system that will be captured by a well. Contributing recharge areas are useful for identifying the parts of the aquifer system that supply water to wells and have utility for assessing a well's vulnerability to contamination.

The FCPC existing and proposed wells reside in an area largely encompassed by and adjacent to a previously published model area of the regional, shallow groundwater system developed using GFLOW (Kelson and others, 2002) (fig. 1). To improve understanding of shallow groundwater flow in the local FCPC area, additional field data collection, model expansion, and model simulations were completed by the USGS, in cooperation with the FCPC. The existing model (Kelson and others, 2002) was spatially expanded to encompass the FCPC wells. The updated model then was recalibrated using new field observations of both lake levels and $\mathrm{Q}_{80}$ streamflows, defined as the flow that is equaled or exceeded 80 percent of the time, (fig. 1 and tables 1 and 2) and then used to delineate areas contributing recharge to wells under an expected pumping regime (average pumping rates) and a maximum expected pumping scenario (maximum pumping rates). The recharge and hydraulic conductivity values chosen for the updated model reflected low-recharge and low-streamflow conditions. 

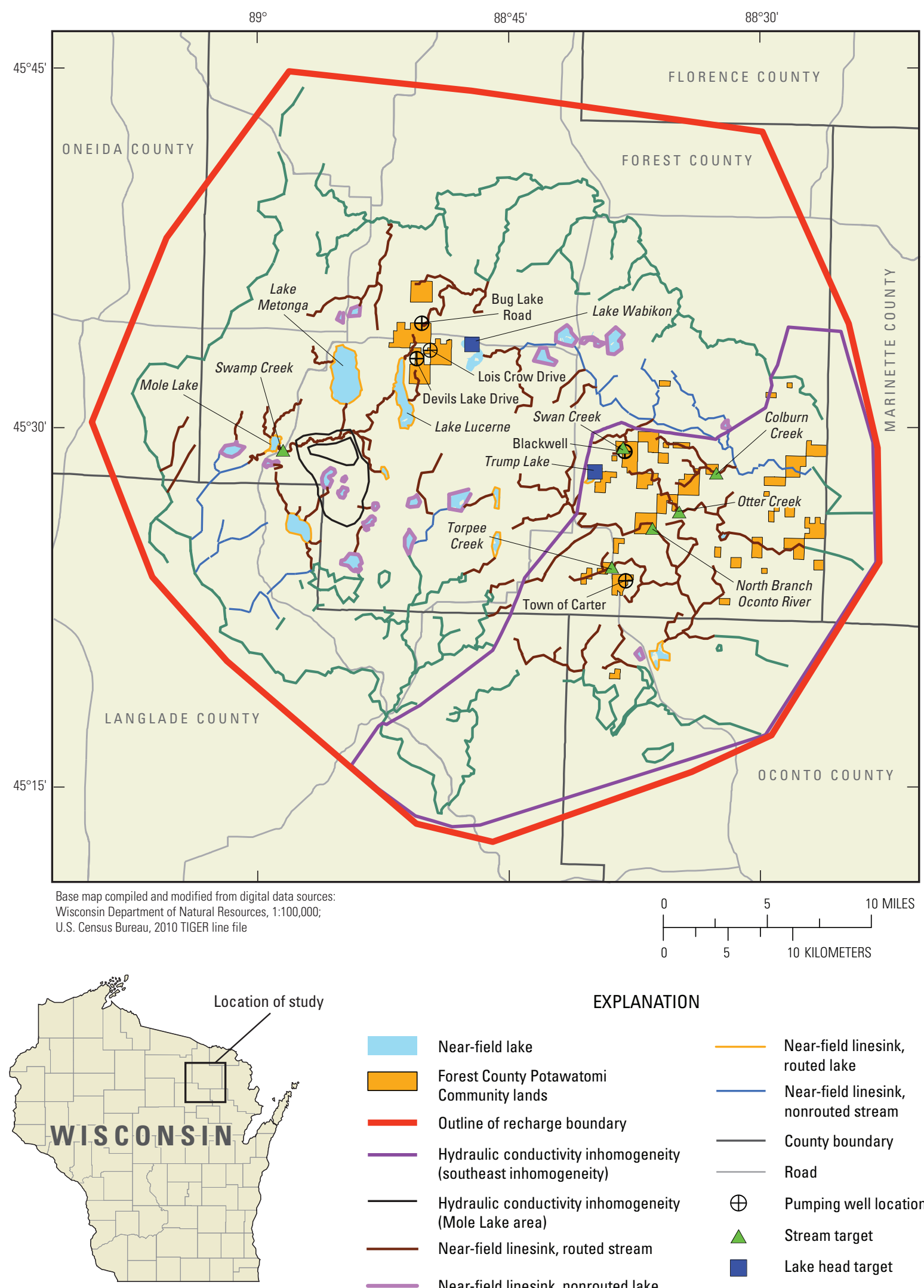

EXPLANATION

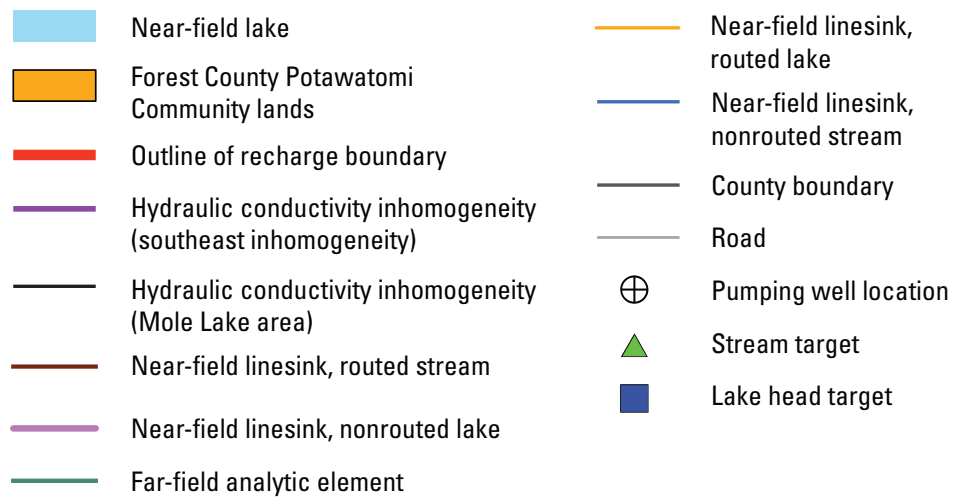

Figure 1. Map showing location of study area in the Forest County Potawatomi Community, Forest County, Wisconsin, and overview of major model elements (modified and expanded from Fienen and others, 2011). 
Table 1. Lake-level measurements (NAVD 88) made during October 25-27, 2010, in the Forest County Potawatomi Community, Forest County, Wisconsin.

\begin{tabular}{lcccccc}
\hline \multicolumn{1}{c}{ Name } & Northing & Easting & $\begin{array}{c}\text { Water } \\
\text { elevation } \\
\text { (meters) }\end{array}$ & $\begin{array}{c}\text { Water } \\
\text { elevation } \\
\text { (feet) }\end{array}$ & $\begin{array}{c}\text { Calibration } \\
\text { target }\end{array}$ & $\begin{array}{c}\text { Constant head } \\
\text { model input }\end{array}$ \\
\hline Lake Lucerne & 5046209.761 & 355664.195 & 499.80 & 1639.76 & & $\mathrm{x}$ \\
Trump Lake & 5037797.132 & 371077.640 & 477.20 & 1565.62 & $\mathrm{x}$ & \\
Lake Wabikon & 5047649.023 & 360574.630 & 483.09 & 1584.95 & $\mathrm{x}$ & \\
Devils Lake & 5045592.429 & 356850.421 & 527.88 & 1731.88 & & $\mathrm{x}$ \\
Lake Metonga & 5046805.969 & 351932.085 & 486.94 & 1597.55 & & $\mathrm{x}$ \\
\hline
\end{tabular}

Table 2. Flow measurements $\left(\mathrm{O}_{80}\right)$ defined as the flow that is equaled or exceeded 80 percent of the time, provided by the Forest County Potawatomi Community, Forest County, Wisconsin, and used as model-calibration targets.

\begin{tabular}{lc}
\hline \multicolumn{1}{c}{ Surface-water site } & $\begin{array}{c}\mathbf{0}_{80} \\
\text { (cubic feet per day) }\end{array}$ \\
\hline Colburn Creek & 325,728 \\
North Branch Oconto & 925,344 \\
Otter Creek (headwater) & 199,584 \\
Swan Creek & 45,792 \\
Torpee Creek & 304,128 \\
Swamp Creek ${ }^{1}$ & $1,709,000$ \\
\hline \multicolumn{2}{|}{ Swamp Creek value taken from Kelson and others } \\
(2002).
\end{tabular}

In order to simulate thinning of the aquifer to the southeast, an additional hydraulic conductivity inhomogeneity was added (fig. 1). Using expanded streamflow data and updated lake levels, the recharge rate for the entire model and hydraulic conductivity in the newly added inhomogeneity were estimated using the general parameter estimation software package, PEST (Doherty, 2010).

In a simple aquifer system, the ultimate source of water to a well is recharge to the water table and the size of a well's area contributing recharge is inversely related to the recharge rate and aquifer porosity for a given pumping rate (Reilly and Pollock, 1993). In this relatively simple aquifer system, low-recharge conditions represent the largest expected areas of contribution, thus forming a conservative endmember of well vulnerability. This motivates the choice for using hydraulic conductivity and recharge values from the " $\mathrm{Q}_{80}$ without Lake Lucerne" scenario of Kelson and others (2002) as a starting point for values in this model. The hydraulic conductivity values in the model area covered by Kelson and others (2002) were originally estimated using a large number of data points. As a result, the hydraulic conductivity values were not updated in the model described in this report. Recharge, on the other hand, was updated to inform the water balance with current (2012) streamflow data. This was done using the Kelson and others (2002) values as a starting point and using the $\mathrm{Q}_{80}$ statistic of expanded streamflow data provided by the FCPC.

\section{Purpose and Scope}

This report describes changes to the regional groundwater model of Kelson and others (2002) used for simulation of the shallow groundwater-flow system near the FCPC in Forest County, Wisconsin, and the surrounding areas. Simulations were performed using the model to delineate the areas contributing recharge to seven existing and three proposed pumping wells corresponding to two pumping scenarios selected by the FCPC. The model and collection of new data focused on the shallow groundwater-flow system in the vicinity of several existing and proposed wells because of the locations of the wells, an emphasis on groundwater and surface-water interactions, and the absence of confining units in the modeled area.

\section{Physical Setting}

The study area (fig. 1) is located in southern Forest County, Wisconsin. The regional groundwater system in the FCPC area is a relatively thin (ranging from about 15 to 150 feet (ft) in thickness) glacial aquifer overlying comparatively impermeable Precambrian igneous and metamorphic rocks (Soller and Packard, 1998). Wells are completed in this thin glacial aquifer. Seepage and drainage lakes are common in the area and affect the groundwater-flow system. Seepage lakes have neither an inlet nor an outlet with water supplied by precipitation, runoff, and groundwater. Drainage lakes have both an inlet and an outlet and, while they may be in contact with the groundwater-flow system, the main source of water is stream drainage (Wisconsin Department of Natural Resources, 1995). The seven existing and three proposed wells are located at five locations (fig. 1). Several of the wells are located near surface-water features. The regional hydrology is discussed in more detail by Kelson and others (2002). In the 1990s, a mine was proposed in the study area, which was the motivation for the Kelson and others (2002) model. 


\section{Data Sources}

With the few exceptions noted in this report, this study is based on the previously published model of Kelson and others (2002). Surface-water elevations for Lucerne, Trump, Wabikon, Devils, and Metonga Lakes were collected during October 25-27, 2010, and the measurements are presented in table 1. Lake stage at two locations-Trump Lake and Lake Wabikon-were used as calibration targets. The other lake stages were entered into the model as boundary conditions representing updated conditions. All surface-water level measurements are reported as feet and are referenced to the North American Vertical Datum of 1988 (NAVD 88). The locations of the existing and proposed groundwater wells were provided by the FCPC. The FCPC also provided streamflow measurements that were used, in conjunction with the USGS Swamp Creek streamgage, as water balance calibration targets pertaining to both the original and expanded domains (table 2). Table 2 reports the $Q_{80}$ flow values, in cubic feet per day, based on the FCPC measurements that span 2 years $(2010-11)$. The $\mathrm{Q}_{80}$ flow value for Swamp Creek, however, is based on Kelson and others (2002).

\section{Methods}

The two-dimensional model used for this study is an Analytic Element Method (AEM) groundwater-flow model (GFLOW, Haitjema, 1995) that was developed for the region by Kelson and others (2002). Hunt (2006) gives a review of applications of the analytic element method, and Haitjema (1995) discusses the underlying concepts and mathematics of the method in detail. A complete description of the AEM is beyond the scope of this report, but a brief description follows.

In AEM, the model domain (model area) is represented by a gridless, infinite aquifer, and the solution accuracy is independent of the grid size. The AEM and comparisons of analytic element to finite-difference numerical-model techniques have been extensively discussed in peer-reviewed literature (Haitjema, 1995; Hunt and Krohelski, 1996; Hunt and others 1998; Hunt and others, 2003; and Hunt, 2006).

To construct an analytic element model, features important for controlling groundwater flow (for example, wells and surface-water features) are entered as mathematical elements or strings of elements. The amount of detail specified for the features depends on distance from the area of interest. Each element is represented by an analytic solution to the groundwater-flow equation. The effects of these individual solutions are added together to form a solution for any location in the simulated groundwater-flow system. Heads and flows can be computed anywhere in the model domain without nodal averaging, because the solution is not confined to a grid. In the GFLOW model used here, the analytic elements are two dimensional and are used only to simulate steady-state conditions - that is, water levels and streamflows that do not vary with time.

The regional GFLOW model of Kelson and others (2002) was originally calibrated with the parameter estimation code, UCODE (Poeter and Hill, 1998) and in this current effort was partially recalibrated to new data using PEST (Doherty, 2010). Details about the original calibration and data are provided in Kelson and others (2002). The partial recalibration using PEST was motivated both by the expanded spatial domain of the original GFLOW model to accommodate the well locations of interest and updated streamflow information that reflects potential changes in recharge rate. These issues and the decisions guiding the use of PEST for partial recalibration are discussed the next section, and details of the recalibration are discussed in a subsequent section.

The spatial domain of the current GFLOW model represents an expansion of the original model. In the southeastern part of the expanded domain, the thickness of the aquifer decreases is evidenced both by field observations of bedrock outcrops and by the depth to bedrock map by Trotta and Cotter (1973). Moreover, an initial trial-and-error calibration produced a better fit to groundwater-head data in that area by effectively decreasing transmissivity. Transmissivity is the product of hydraulic conductivity and aquifer thickness and, in two-dimensional modeling such as in this case, transmissivity governs groundwater flow through the aquifer. As a result, by enforcing a uniform thickness for the entire model domain, adjusting hydraulic conductivity is an effective way to account for an anomaly of transmissivity.

The techniques described in this report take into account more of the aquifer dynamics than the fixed-radius method used by Watkins (2004). In the fixed-radius method, the equation used is

$$
r=\sqrt{\frac{Q t}{\pi n H}}
$$

where

$\begin{aligned} r & \text { is the radius, } \\ Q & \text { is the pumping rate, } \\ t & \text { is the time of pumping, } \\ \pi & \text { is the mathematical constant, } \\ n & \text { is the porosity, and } \\ H & \text { is the aquifer thickness. }\end{aligned}$

For comparison to the Watkins (2004) results, in the figures showing areas contributing recharge, the radii calculated using the fixed-radius method are depicted as yellow circles. 


\section{Development of a Conceptual Model of the Shallow Groundwater-Flow System}

Before simulating the groundwater system using a flowmodeling code, a conceptualization of the hydrologic system is essential because it forms the framework for model development and reduces the groundwater system into important component parts that can be implemented in the flow model. This reduction is a necessary simplification of the hydrologic system because inclusion of all of the complexities into a model is not feasible. Steps in the development of the conceptual model include (1) characterization of the aquifer(s), (2) identification of sources and sinks of water, and (3) identification and delineation of hydrologic features in the area of interest.

In the aquifer, groundwater enters through recharge and moves from areas of higher groundwater levels to areas of lower groundwater levels and generally discharges to surface-water features or pumping wells. Accurate locations of surface-water features and pumping wells are, therefore, critical to simulating the local groundwater-flow system in the vicinity of the FCPC.

\section{Description of the Regional GFLOW Model}

The existing regional GFLOW model used in this report was developed by Kelson and others (2002) to investigate potential impacts to streamflow and groundwater head owing to a proposed mining site. The mining site described by Kelson and others (2002) was proposed to target an ore body in the area generally indicated by hydraulic conductivity inhomogeneities east of a streamgage on Swamp Creek, as identified in figure 1 . The 1,400 -square-mile $\left(\mathrm{mi}^{2}\right)$ regional model, outlined in figure 1 by the recharge-area boundary, encompasses most of the southern half of Forest County and the area of the existing and proposed wells.

Initial model development by Kelson and others (2002) included estimating the elevation of the base of the groundwater system, horizontal hydraulic conductivity, and recharge rate. The base of the model $(1,200 \mathrm{ft}$ above NAVD 88$)$ roughly corresponds with the top of the crystalline bedrock in the eastern portion of the model. In a single-layer GFLOW model, it is common to maintain constant aquifer base elevation and to adjust hydraulic conductivity values during the model calibration. As a result, aquifer base elevation was held constant and not varied during model calibration. Horizontal hydraulic conductivity was assigned one of three values corresponding to different inhomogeneities identified in figure 1. To account for aquifer thinning (and therefore lower transmissivity) in the expanded model domain, a fourth hydraulic conductivity zone, implemented as an inhomogeneity zone, was outlined in the southeastern part of the model domain. Hydraulic conductivity values for the newly added inhomogeneity value and the regional groundwater-recharge value were considered calibration parameters and were varied during model calibration.
The parameters were estimated using calibration targets that included head values in wells and stream discharge at six locations during "low-flow" periods - referred to as the $\mathrm{Q}_{80}$ flow and defined as the flow that is equaled or exceeded 80 percent of the time - as discussed by Kelson and others (2002). The size of areas contributing recharge to wells is approximately inversely related to recharge value: higher values of recharge results in smaller areas contributing recharge for a given pumping rate (Bhatt, 1993). Therefore, estimating recharge corresponding to $\mathrm{Q}_{80}$ flow conditions results in a relatively lower estimated value of recharge and correspondingly larger areas contributing recharge. This can be considered a conservative estimate of the well's capture, because its larger size provides a larger margin of safety when evaluating potential source areas to the well for a given time horizon.

Published values of horizontal hydraulic conductivity for the original model included $33 \mathrm{ft} / \mathrm{d}$ for the regional glacial and sandstone aquifer and 11 and $19 \mathrm{ft} / \mathrm{d}$ for two local inhomogeneity inclusions located to the east of Mole Lake (fig. 1). Groundwater recharge in the original model was $7.2 \mathrm{in} / \mathrm{yr}$ (Kelson and others, 2002). All of these values were estimated assuming $\mathrm{Q}_{80}$ flow conditions.

In the updated calibration performed for this report, the three hydraulic conductivity zones present in the original model were held at their previously calibrated values while the hydraulic conductivity in the southeastern inhomogeneity zone was estimated as $2.5 \mathrm{ft} / \mathrm{d}$. Recharge, calibrated with the expanded streamflow dataset covering the entire model domain, was estimated to be $6.4 \mathrm{in} / \mathrm{yr}$. This value is lower than the value from Kelson and others (2002) and reflects drier conditions, which have been experienced in the area since the Kelson and others (2002) study.

The groundwater-flow model consists of far-field and near-field elements where the latter reflect the area of interest and are characterized by more sophisticated representation of surface-water features and focused field data collection. The main changes to the original Kelson and others (2002) model are (1) refinement of channel geometry for Swamp Creek and the shoreline of Rice Lake, performed by Fienen and others (2011) and based on USGS topographic 7.5-minute quadrangle data; (2) refinement of the surface-water features near the northern well locations; and (3) expansion of the model domain, incorporating new surface-water features to the southeast. On the basis of the conceptual model, the location and elevation of far-field surface-water features were included from the Kelson and others (2002) model (fig. 1). These features are rivers and lakes distant from the well locations and are simulated with coarse linesink networks and little or no resistance between the surface-water features and the groundwater system. Some features that were in the far field in the Kelson and others (2002) model were refined and turned into near-field elements in the expansion of the model, and new far-field elements were added to the model. Because an infinite aquifer extent is assumed in the AEM, the purpose of simulating the far-field features is to have the model explicitly 
Simulation of the Shallow Groundwater-Flow System in the Forest County Potawatomi Community, Wisconsin

simulate the general groundwater flow in the region and to buffer the near-field area of interest from boundary effects. The near-field area is focused around the FCPC lands and encompasses the locations of all the existing and proposed wells.

Streambed resistance in the near field was set to 0.3 day by Kelson and others (2002). Resistance is defined as the streambed-sediment thickness divided by the vertical hydraulic conductivity. For example, the model value of 0.3 day corresponds to a $1 \mathrm{ft}$ sediment thickness and a vertical hydraulic conductivity of $3 \mathrm{ft} / \mathrm{d}$. Parameter sensitivity assessments (Kelson and others, 2002) demonstrated that the model results were not sensitive to changes in streambed resistance when varied over reasonable ranges; therefore, the values for all streams were fixed in all model runs. The width of each stream was assigned according to stream order and field observations and ranged from 10 to $100 \mathrm{ft}$.

Lakes, except Trump Lake and Lake Wabikon (discussed below), were simulated using linesinks with resistance and streamflow routing in the near field. Drainage lakes (lakes that have a stream outlet) in the near field were linked to the stream network by stream elements, based on the methods of Hunt and others (1998). Within the perimeter of each lake, the recharge rate applied to the lake represents net precipitation rather than groundwater recharge; therefore, the water added to the lakes differs from that of the regional aquifer. (This can be expressed by the equation $R_{\text {lake }}=P-E_{\text {lake }}$; where $R_{\text {lake }}$ is the net precipitation recharged inside the lake, $P$ is the annual precipitation, and $E_{\text {lake }}$ is the evaporation rate from the lake.) The net precipitation recharged inside all near-field lakes in the model was set equal to $2.3 \mathrm{in} / \mathrm{yr}$. The value of lake linesink resistance was set to 0.3 day for all near-field lakes. The width assigned to linesinks representing lakes was one-half the length of the shortest axis of the lake represented by the linesink. The stage of lakes was assigned either from map values or specific measurements made using site-specific measurements discussed in the next section.

The stage for Trump Lake and Lake Wabikon was calculated by GFLOW and used as a calibration target, rather than assigning the stage from field measurements. Trump Lake is a seepage lake so the only additional information necessary to explicitly calculate stage is a stage-volume relation that is obtained from bathymetry on USGS 7.5-minute topographic maps. As a result, Trump Lake was simulated using explicit calculation in GFLOW. Lake Wabikon, on the other hand, is a drainage lake. To simulate lake stage in Lake Wabikon, explicitly using the lake package of GFLOW in addition to the readily available stage-volume relation, a stage-discharge relation for the outlet stream also would be required. This information, however, exceeded the scope of this report, so instead, stage was calculated by simulating a piezometer in a high hydraulic conductivity $(10,000 \mathrm{ft} / \mathrm{d}$ greater than the background value of $33 \mathrm{ft} / \mathrm{d}$ ) zone representing the lake. This approximate method (Hunt and Krohelski, 1996) is not as accurate as the full water balance calculated by including stage-discharge information, but absent that extra information, it is the most appropriate option.

The only pumping simulated in the model during calibration was from the existing wells identified later in figures 3-11. To calculate areas contributing recharge, pumping from proposed wells was added to subsequent scenario runs.

\section{Updating Lake Stage Information}

The regional groundwater-flow model was expanded to encompass the areas to the east and south of the original model by Kelson and others (2002), where the FCPC has existing and proposed wells. Surface-water features were added by digitizing linesinks based on USGS topographic 7.5-minute quadrangle maps. In the areas near wells, previously constructed linesinks by Kelson and others (2002) also were refined by redigitizing with greater detail based on the same quadrangle maps. Updated lake stages were measured during October 25-27, 2010, as discussed previously, using a realtime kinematic (RTK) global-positioning system (GPS). This RTK-GPS system is capable of providing sub-inch level accuracy, both vertically and horizontally, by differentially correcting GPS signals recorded at two separate GPS receivers (Wolf and Ghilani, 2002). The field survey was horizontally referenced to the Universal Transverse Mercator coordinate system and the North American Datum of 1983 (NAD 83), as well as the 1997 adjustment of NAD 83 via the Wisconsin High Accuracy Reference Network; it was vertically referenced to NAVD 88. Table 1 reports the measurements of lake stage used in the model either as updated stages or, in the case of Trump Lake and Lake Wabikon, as recalibration targets.

\section{Partial Recalibration using PEST}

The general parameter estimation software package, PEST (Doherty, 2010) was used to determine optimal values of recharge over the entire model domain and hydraulic conductivity in the inhomogeneity representing the thinning of the aquifer in the southeastern part of the model. To use PEST, calibration targets are selected representing model outputs for which field observations are available collocated in time and space. For this model, the targets were streamflow in several stream reaches and two lake-stage values. PEST uses a mathematical algorithm (Gauss-Levenberg-Marquardt) to adjust parameters systematically, resulting in close correspondence between model outputs and the corresponding field measurements. This correspondence, for mathematical reasons, is calculated as the sum of the squared differences between modeled and measured values, each divided by a weight. The user controls how closely the algorithm will make this correspondence (called "fit") based on the weights assigned to the targets. Perfect correspondence is neither possible nor desired because uncertainty owing both to measurement techniques 
and imperfection of the model is always present. For this application, the relative quality of the lake-stage targets was deemed to be greater than that of the streamflow targets. As a result, the weight of the lake-stage targets was set at 1.0 while the weights of the streamflow targets were set at the inverse of the target value. While more robust weighting practices are possible in theory (for example, using quantified standard deviation of target values), the uncertainty depends on factors (especially model imperfections) that are impossible to truly quantify. In this application, the qualitative assignment of weights represents expert knowledge about both the model and the system, and weights were assigned based on such criteria.

The decision not to recalibrate all parameters in the model was motivated by the fact that the previous calibration of hydraulic conductivity was made based on many data points used by Kelson and others (2002). Hydraulic conductivity is an inherent property that, in an aquifer like this one, does not change over time. Recharge, on the other hand, can change owing to climate variability in addition to inherent material properties. Recharge also represents an important factor in controlling the water balance of the system. The expansion of the model domain, therefore, combined with a more recently available dataset, motivated recalibration of recharge. The hydraulic conductivity inhomogeneity that was added to represent thinning of the aquifer also is outside the domain of the Kelson and others (2002) model. The conceptualization of thinning of the aquifer was implemented by drawing the zonal boundary, but the degree to which the resulting change in hydraulic conductivity was implemented needed to be informed by the site-specific data, so recalibration was necessary for that parameter.

The modeled lake-stage targets, after partial recalibration, matched the field measurements to within $0.1 \mathrm{ft}$. The streamflow results were not as close, both as expected owing to their temporal uncertainty and as enforced through weighting. Figure 2 shows a comparison of measured and modeled streamflow results both before and after partial recalibration. The largest changes owing to partial recalibration were seen in the values with the largest magnitude: namely, North Branch of the Oconto River and Swamp Creek. These two targets also are expected to have the largest residuals (difference between measured and simulated values). The target data for Swamp Creek predates the recalibration data for the expanded model area. As a result, the residual at Swamp Creek was expected to be higher than at other locations. The North Branch of the Oconto River has a headwater section in the main hydraulic conductivity region of the model but crosses the boundary to the southeast hydraulic conductivity inhomogeneity as it progresses downstream. The oversimulation of flow in the North Branch of the Oconto River could be mitigated by increasing hydraulic conductivity of either hydraulic conductivity inhomogeneity in the model. The fact that the North Branch of the Oconto River observation is affected by attributes of more than one hydraulic conductivity inhomogeneity results in less leverage on either inhomogeneity. The residuals in the other observations are already low, so a compromise in the North Branch of the Oconto River observation is required and a lower residual is not obtainable.

\section{Simulation of the Shallow Groundwater-Flow System to Assess Areas Contributing Recharge to Existing and Proposed Wells in the Forest County Potawatomi Community}

Existing and proposed wells at five locations were the subject of the analysis in this report. In this section, the simulated areal extent of areas contributing recharge to each of the proposed and existing wells are presented and discussed. Areas contributing recharge were assessed using the GFLOW model adapted to the FCPC area conditions as discussed earlier in this report. The areas contributing recharge to the wells were delineated by backward particle tracking from the well to the area of recharge. Mathematical particles of water were placed within the well screen at the bottom of the aquifer and traced backwards toward the water table for 5- and 10 -year periods using the updated model. The well screens were simulated as fully penetrating the aquifer thickness. By use of a porosity of 0.2 , which is on the lower end of the range and typical of sand (Freeze and Cherry, 1979), estimates of the time required for a particle of water in the contributing area to reach the well also were calculated. Using the lower range porosity value is conservative because lower porosity results in higher velocity which, in turn, results in larger areas contributing recharge for the specified time scales. Simulated areas contributing recharge are shown in figures 3-13 for 5and 10 -year travel times.

For each location, except the town of Blackwell, two pumping rates were evaluated: an average pumping rate and a maximum pumping rate. The average pumping rate corresponds to typical pumping conditions, while the maximum rate is an estimate of the highest rate (and thus the largest area contributing recharge) that might be anticipated as a sensitivity run. All pumping rates were provided by the FCPC. At Blackwell, the wells were not yet installed when the analysis was performed, so only the average representative rate was provided by the FCPC. Table 3 shows the pumping rates for each well and figure 1 shows the locations of the wells. 

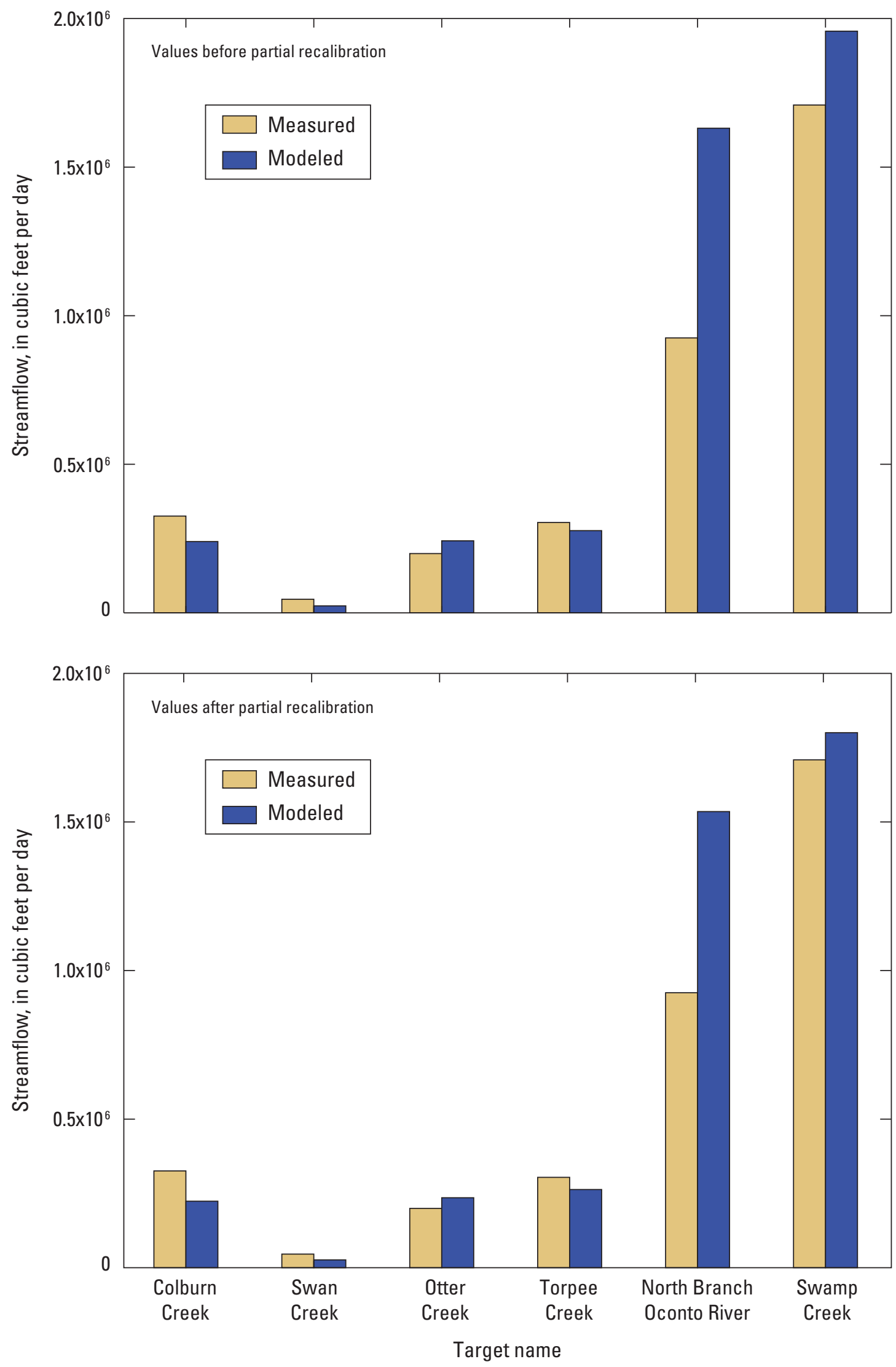

Figure 2. Chart showing measured and modeled results for streamflow targets before (top panel) and after (bottom panel) partial recalibration of the GFLOW model by using PEST. 
Table 3. Existing and proposed wells with both average and maximum flow rates, provided by the Forest County Potawatomi Community, Forest County, Wisconsin.

[N/A, not applicable]

\begin{tabular}{lcc}
\hline Well name & $\begin{array}{c}\text { Average } \\
\text { flow rate } \\
\text { (gallons } \\
\text { per minute) }\end{array}$ & $\begin{array}{c}\text { Maximum } \\
\text { flow rate } \\
\text { (gallons } \\
\text { per minute) }\end{array}$ \\
\hline Lois Crow Drive & 25 & 30 \\
Devils Lake North & 11 & 17 \\
Devils Lake South & 34 & 40 \\
Bug Lake North & 89 & 150 \\
Bug Lake South & 70 & 80 \\
Carter North & 60 & 105 \\
Carter North Additional & 80 & 100 \\
Carter South & 88 & 88 \\
Blackwell North & 60 & N/A \\
Blackwell South & 60 & N/A \\
\hline
\end{tabular}

Figures 3 and 4 show the simulated areas contributing recharge for the wells at Bug Lake Road under average and maximum pumping rates, respectively. Under average conditions, the simulated areas contributing recharge do not intersect any surface-water features, although at maximum conditions, the simulated area contributing recharge for the Bug Lake North well at 10-year travel time intersects Bug Lake.

Figures 5 and 6 show the simulated area contributing recharge for the well at Lois Crow Drive under average and maximum pumping rates, respectively. Under average and maximum conditions, the simulated areas contributing recharge do not intersect any surface-water features. However, several houses are located within the 5-year area.

Figures 7 and 8 show the simulated areas contributing recharge for the wells at Devils Lake Lane under average and maximum pumping rates, respectively. Under average and maximum conditions, the simulated areas contributing recharge do not intersect any surface-water features. Three buildings are within the simulated areas contributing recharge.

Figure 9 shows the simulated areas contributing recharge for the North and South wells at the town of Blackwell under the average pumping conditions. The simulated 10 -year area contributing recharge for the Blackwell North well intersects Swan Creek.

Figures 10 and 11 show the simulated areas contributing recharge for the wells at the town of Carter under average and maximum pumping rates, respectively. Under average and maximum conditions, the simulated areas contributing recharge intersect the infiltration ponds north of the casino. These ponds may be a potential source of water to the Carter North and Carter South wells.

Figures 12 and 13 show the simulated areas contributing recharge for the wells at the town of Carter under average and maximum pumping rates, respectively, with an additional proposed well simulated further north of the Carter North well. Under average and maximum conditions, the simulated areas contributing recharge from the original Carter North and Carter South wells intersect the ponds north of the casino, and the simulated area contributing recharge for the additional proposed well further north is limited to forested land.

\section{Assumptions and Limitations}

Given the relatively high hydraulic conductivity of the aquifer, relatively high net annual precipitation, and presence of springs and perennial headwater streams, the groundwater and surface-water systems are assumed to be in close hydrologic connection in the study area, and elevations of surfacewater features are assumed to be approximate water levels for the underlying groundwater system. A single-layer groundwater-flow model was assumed to be appropriate for this application because the groundwater-flow system is relatively thin and laterally extensive. Steady-state conditions were assumed to be appropriate for this system because hydraulic conductivity is high, and distances between surface-water features are relatively small (Kelson and others, 2002). These characteristics help dampen the effects of periodic transient stresses applied to the system (Haitjema, 1995). Steady-state assumptions, which ignore groundwater release from storage, can be expected to result in an estimate of the higher range of system response (such as water-level drawdown owing to pumping) to a hydrologic stress.

Limitations of the model result from these assumptions. Namely, local three-dimensional flow and transient system response expected near wells and surface-water features are only approximately represented. In addition, local features of the groundwater system (for example, local variations in hydraulic conductivity and recharge) are only approximated by the parameterization used in the regional model of Kelson and others (2002).

The calibration of the model performed by Kelson and others (2002) was partially updated to account for the expanded areal extent of the present model. The hydraulic conductivity values in the original Kelson and others (2002) model were retained as they were informed by more data than the new measurements in the expanded area. Recharge, however, is expected to change in response to climatic variability, so the recharge value was updated. 


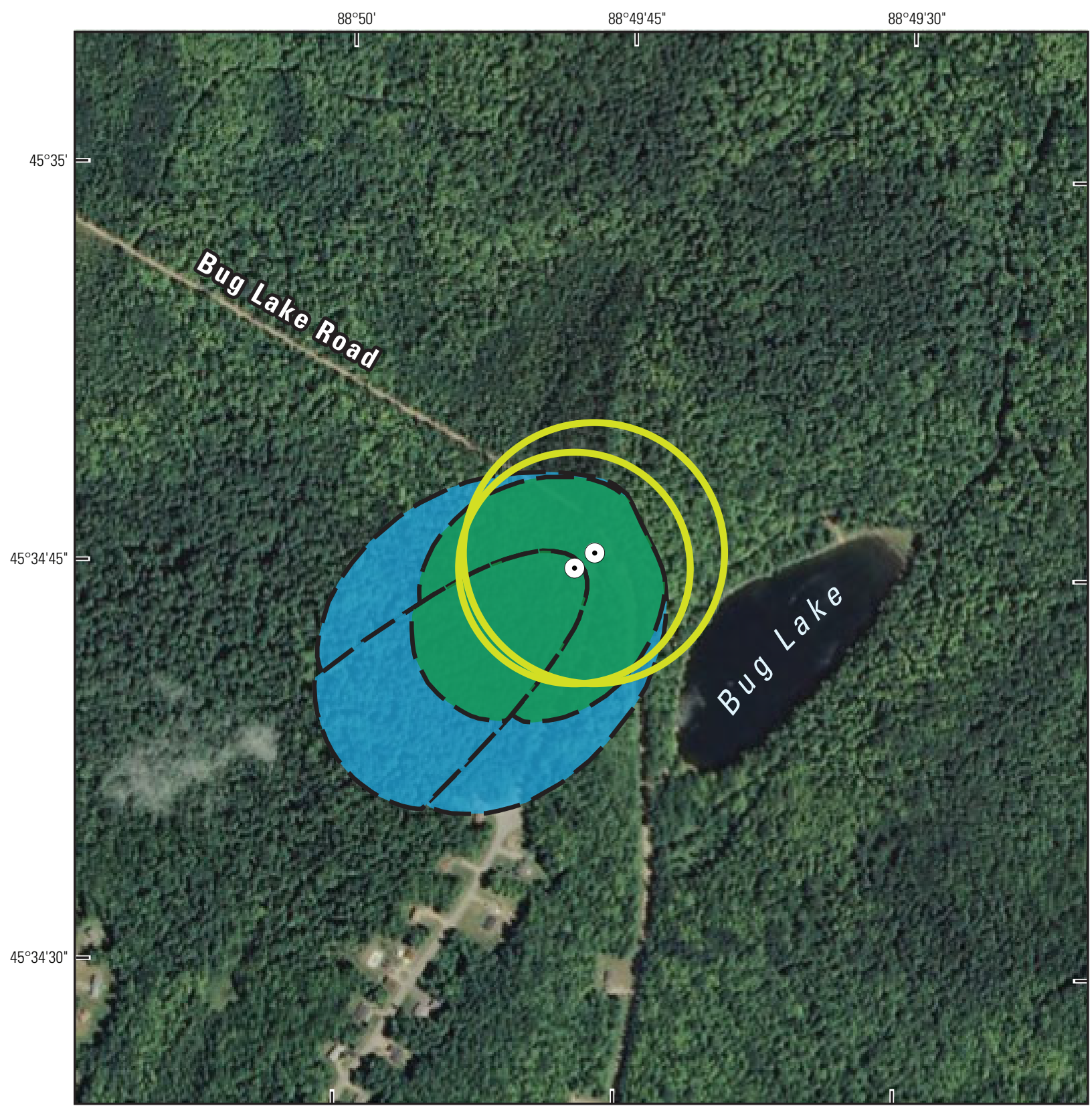

Base map from digital data sources: ESRI USA Imagery (2010)

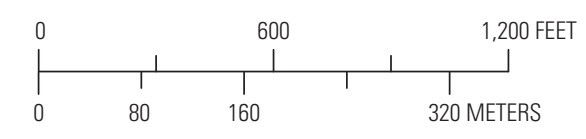

\section{EXPLANATION}

5-year area contributing recharge (average)

10-year area contributing recharge (average)

5-year area contributing recharge of each well, calculated by fixed radius method (Watkins, 2004)

$-\quad$ Pumping well

Figure 3. Map showing simulated areas contributing recharge using the GFLOW model for average pumping conditions (North well, 89 gallons per minute; South well, 70 gallons per minute) at Bug Lake Road, Forest County Potawatomi Community, Forest County, Wisconsin. 


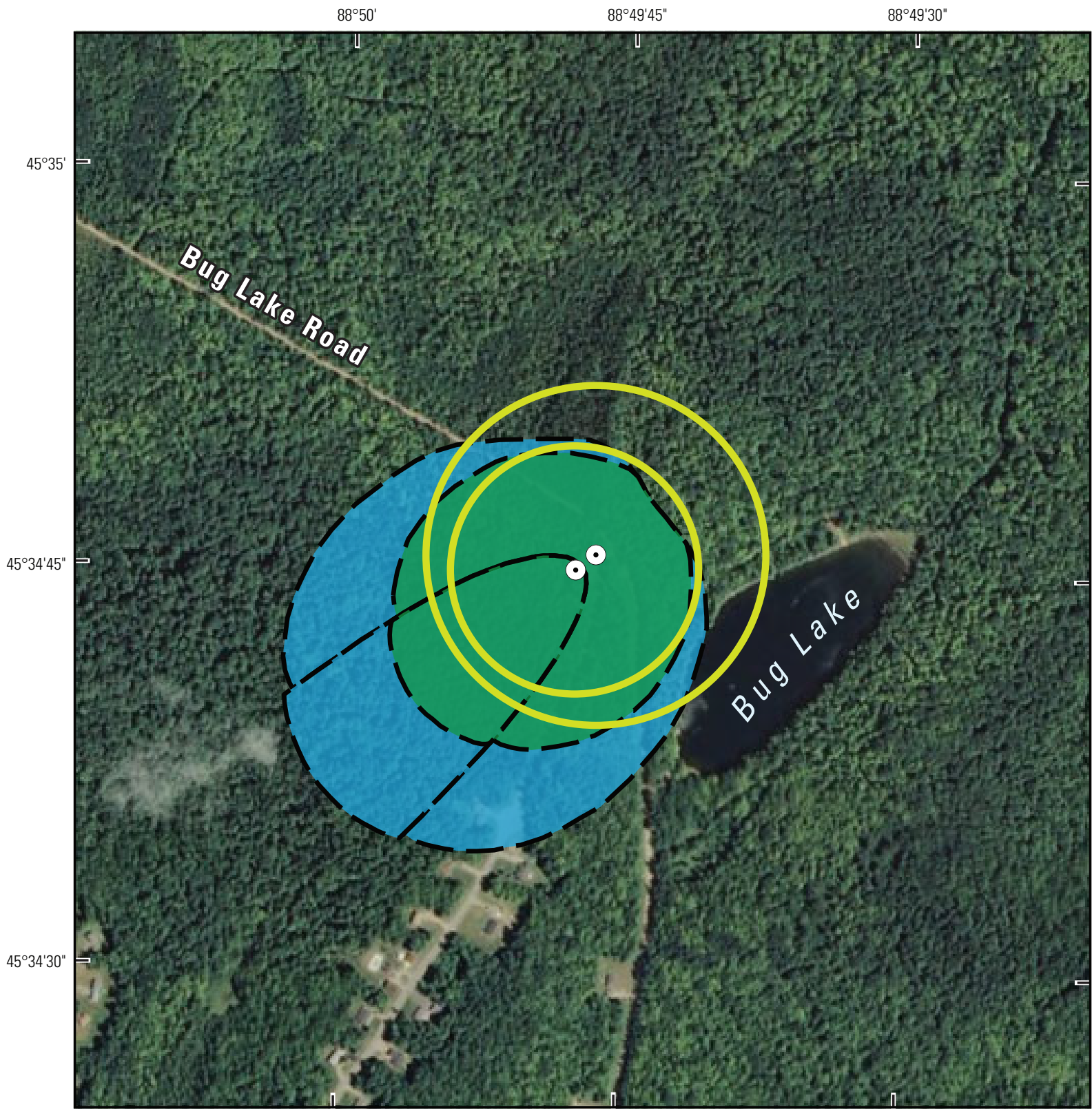

Base map from digital data sources: ESRI USA Imagery (2010)

\section{EXPLANATION}

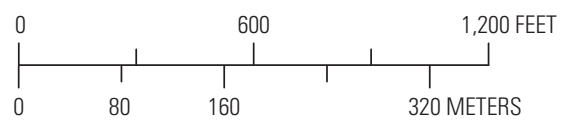

5-year area contributing recharge (average)

10-year area contributing recharge (average)

5 -year area contributing recharge of each well, calculated by fixed radius method (Watkins, 2004)

$\odot \quad$ Pumping well

Figure 4. Map showing simulated areas contributing recharge using the GFLOW model for maximum pumping conditions (North well, 150 gallons per minute; South well, 80 gallons per minute) at Bug Lake Road, Forest County Potawatomi Community, Forest County, Wisconsin. 


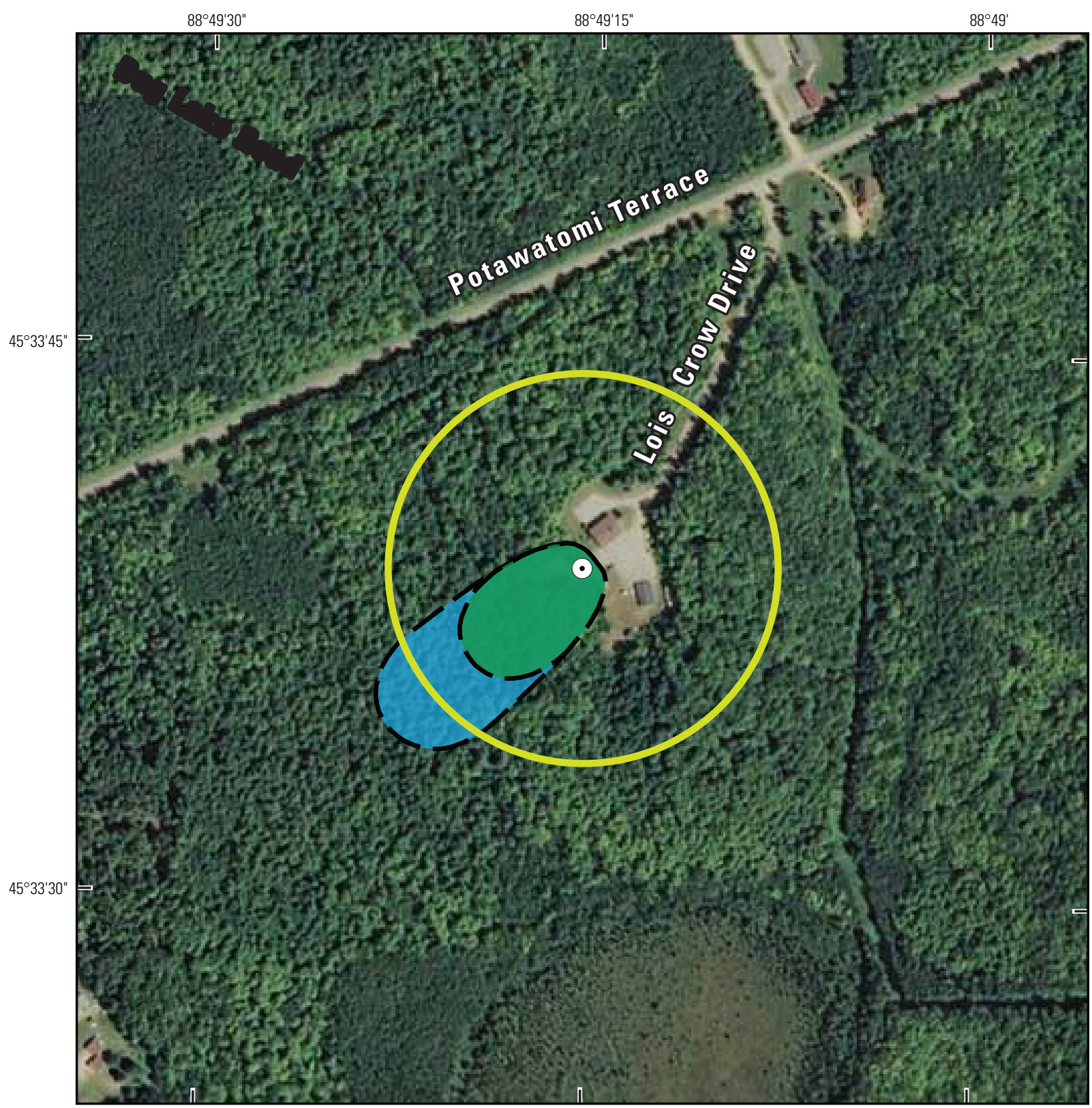

Base map from digital data sources: ESRI USA Imagery (2010)

\section{EXPLANATION}

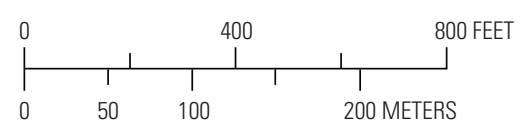

5-year area contributing recharge (average)

10-year area contributing recharge (average)

5 -year area contributing recharge of each well, calculated by fixed radius method (Watkins, 2004)

- Pumping well

Figure 5. Map showing simulated areas contributing recharge using the GFLOW model for average pumping conditions (25 gallons per minute from each well) at Lois Crow Drive, Forest County Potawatomi Community, Forest County, Wisconsin. 


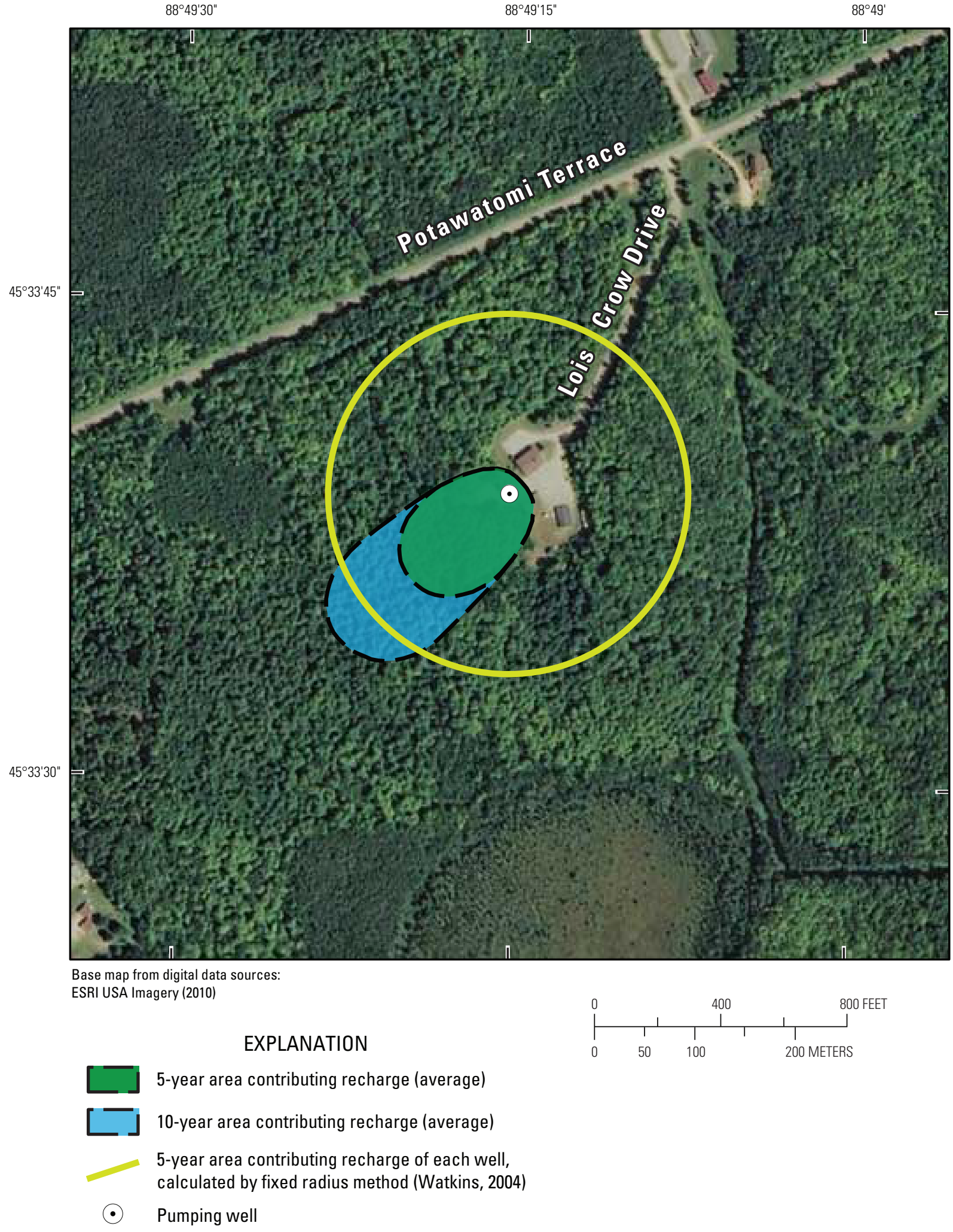

Figure 6. Map showing simulated areas contributing recharge using the GFLOW model for maximum pumping conditions ( 30 gallons per minute from each well) at Lois Crow Drive, Forest County Potawatomi Community, Forest County, Wisconsin. 


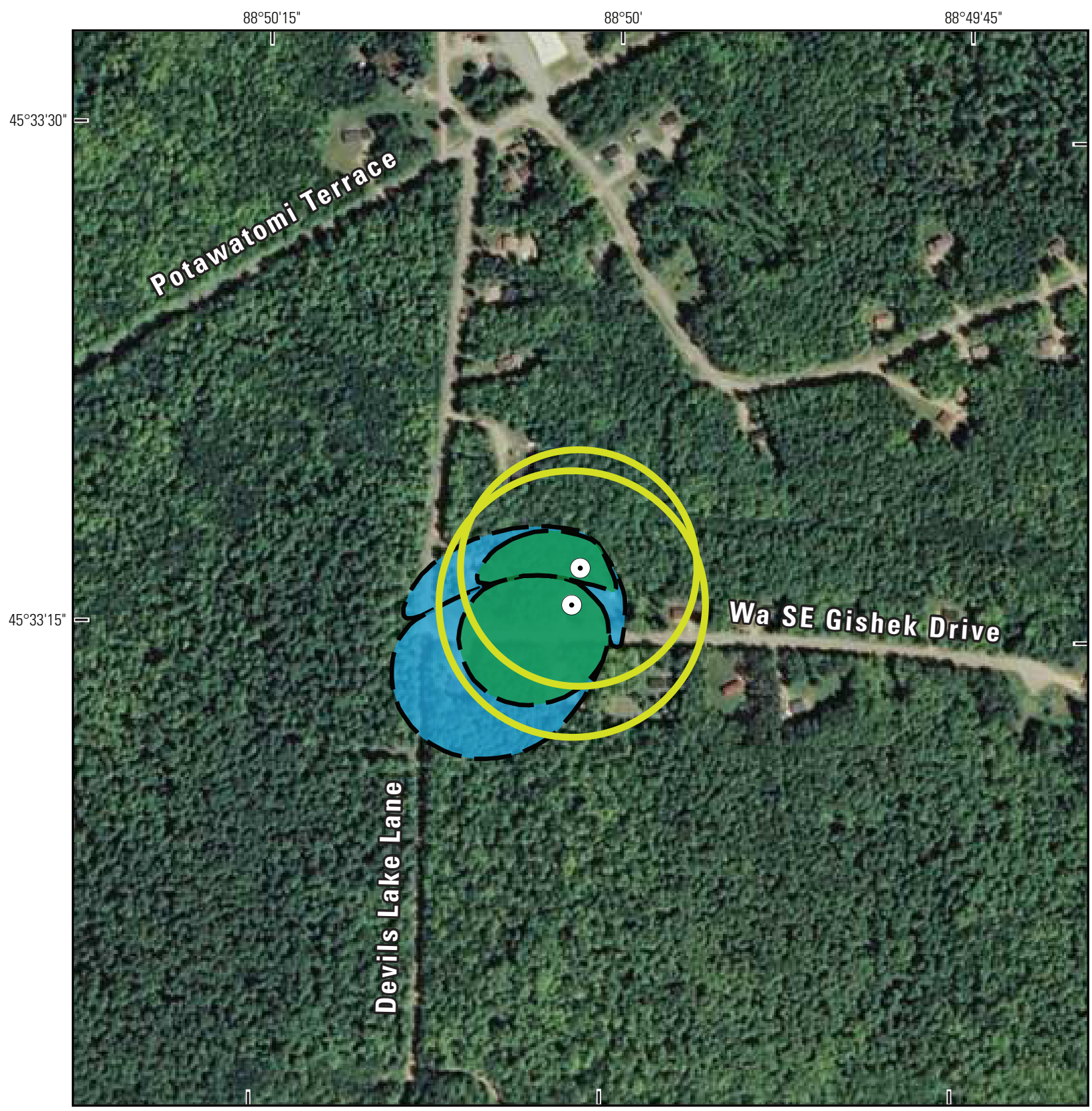

Base map from digital data sources:

ESRI USA Imagery (2010)

\section{EXPLANATION}

5-year area contributing recharge (average)
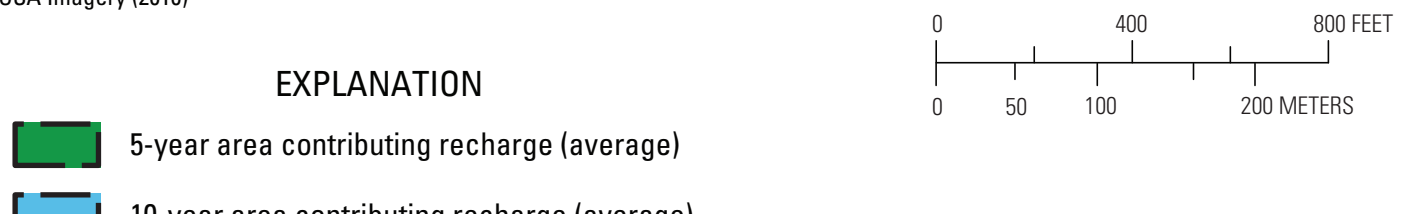

10-year area contributing recharge (average)

5 -year area contributing recharge of each well, calculated by fixed radius method (Watkins, 2004)

- Pumping well

Figure 7. Map showing simulated areas contributing recharge using the GFLOW model for average pumping conditions (North well, 11 gallons per minute; South well, 34 gallons per minute) at Devils Lake Lane, Forest County Potawatomi Community, Forest County, Wisconsin. 


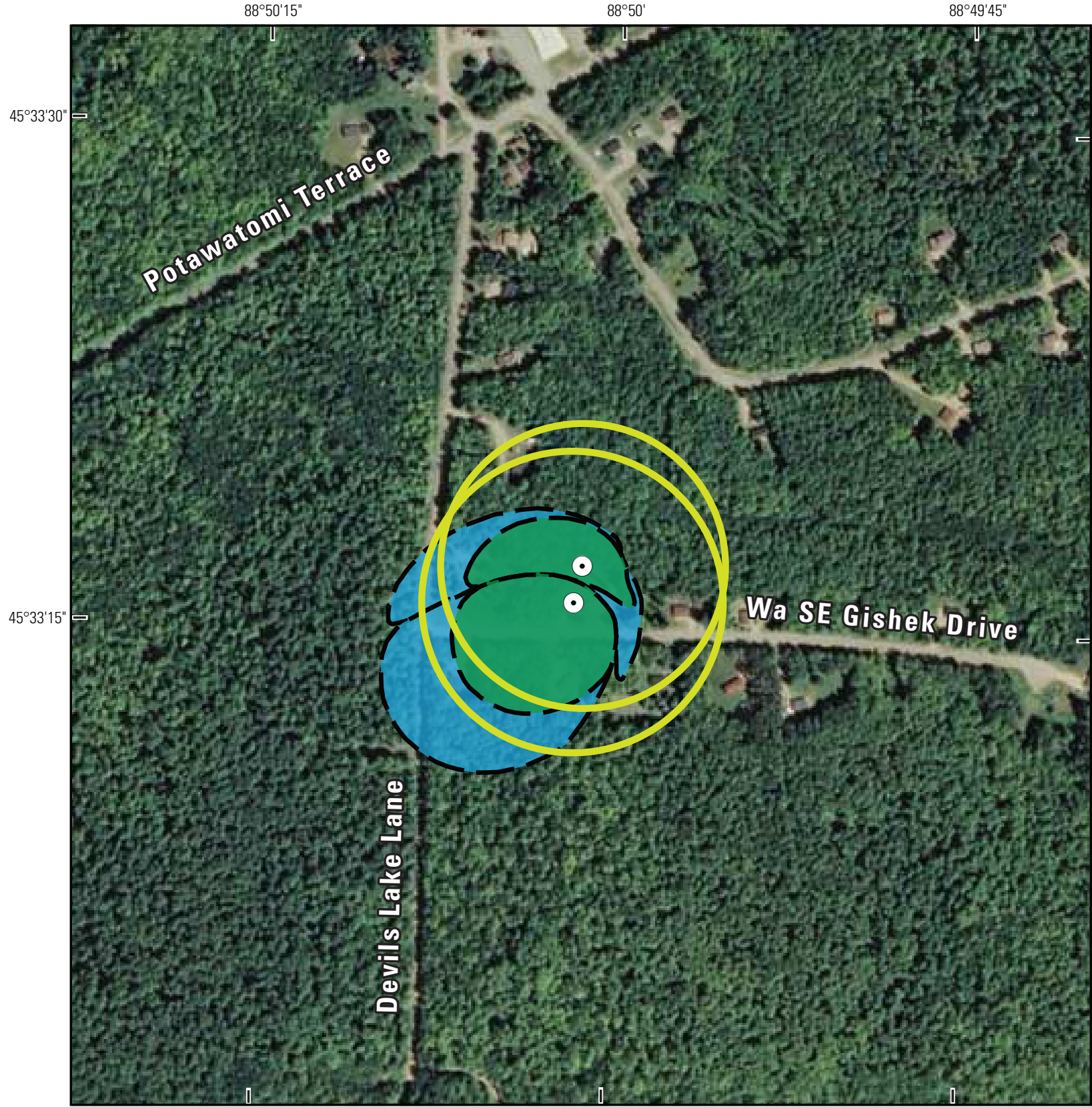

Base map from digital data sources:

ESRI USA Imagery (2010)

\section{EXPLANATION}

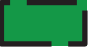

5-year area contributing recharge (average)

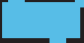

10-year area contributing recharge (average)

5 -year area contributing recharge of each well, calculated by fixed radius method (Watkins, 2004)

$\odot$ Pumping well

Figure 8. Map showing simulated areas contributing recharge using the GFLOW model for maximum pumping conditions (North well, 17 gallons per minute; South well, 40 gallons per minute) at Devils Lake Lane, Forest County Potawatomi Community, Forest County, Wisconsin. 


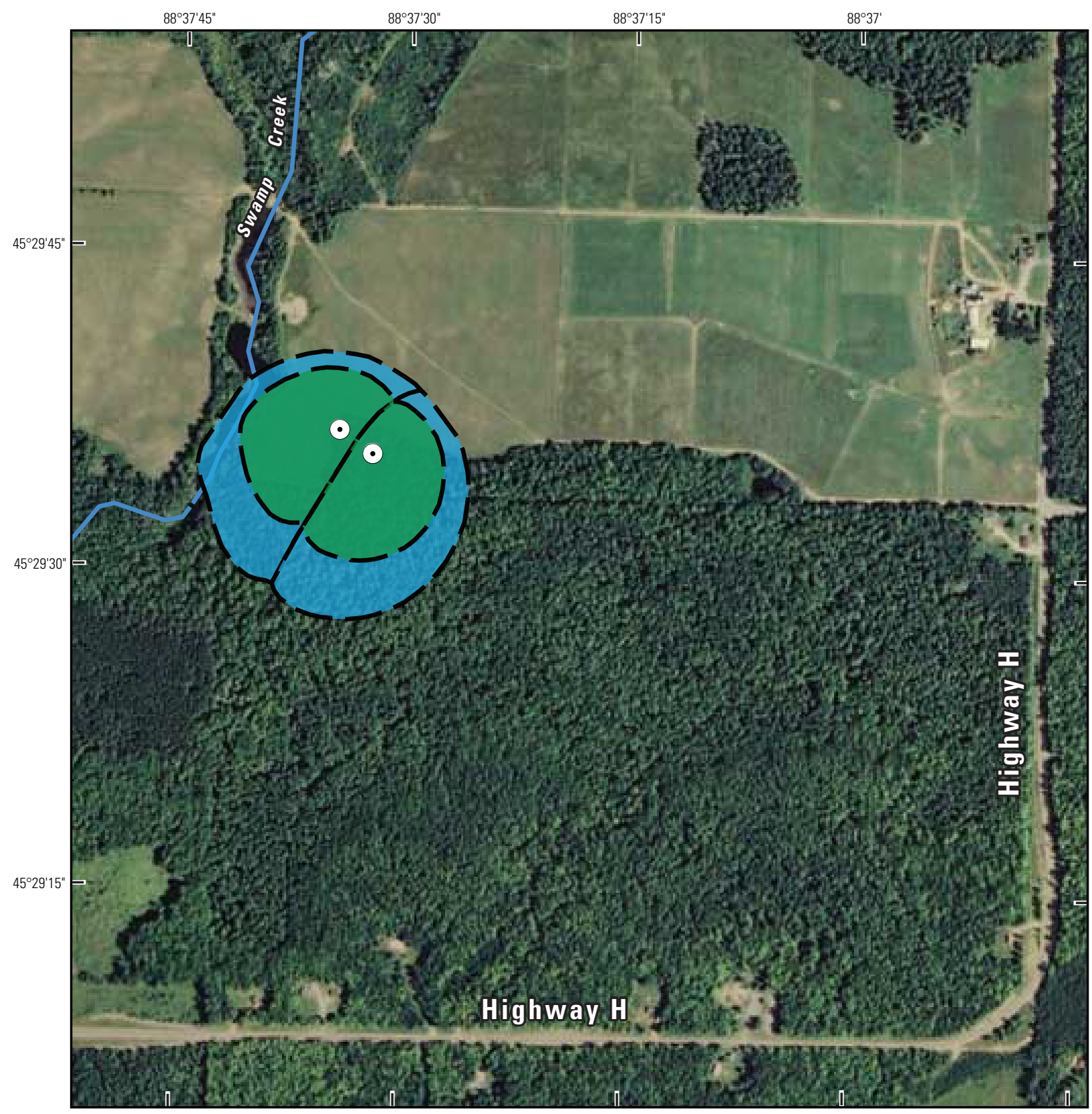

Base map from digital data sources: ESRI USA Imagery (2010)

\section{EXPLANATION}

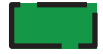

5-year area contributing recharge (average)

[」10-year area contributing recharge (average)

$\odot \quad$ Pumping well

Figure 9. Map showing simulated areas contributing recharge using the GFLOW model for average pumping conditions ( 60 gallons per minute from each well) at the town of Blackwell, Forest County Potawatomi Community, Forest County, Wisconsin. 


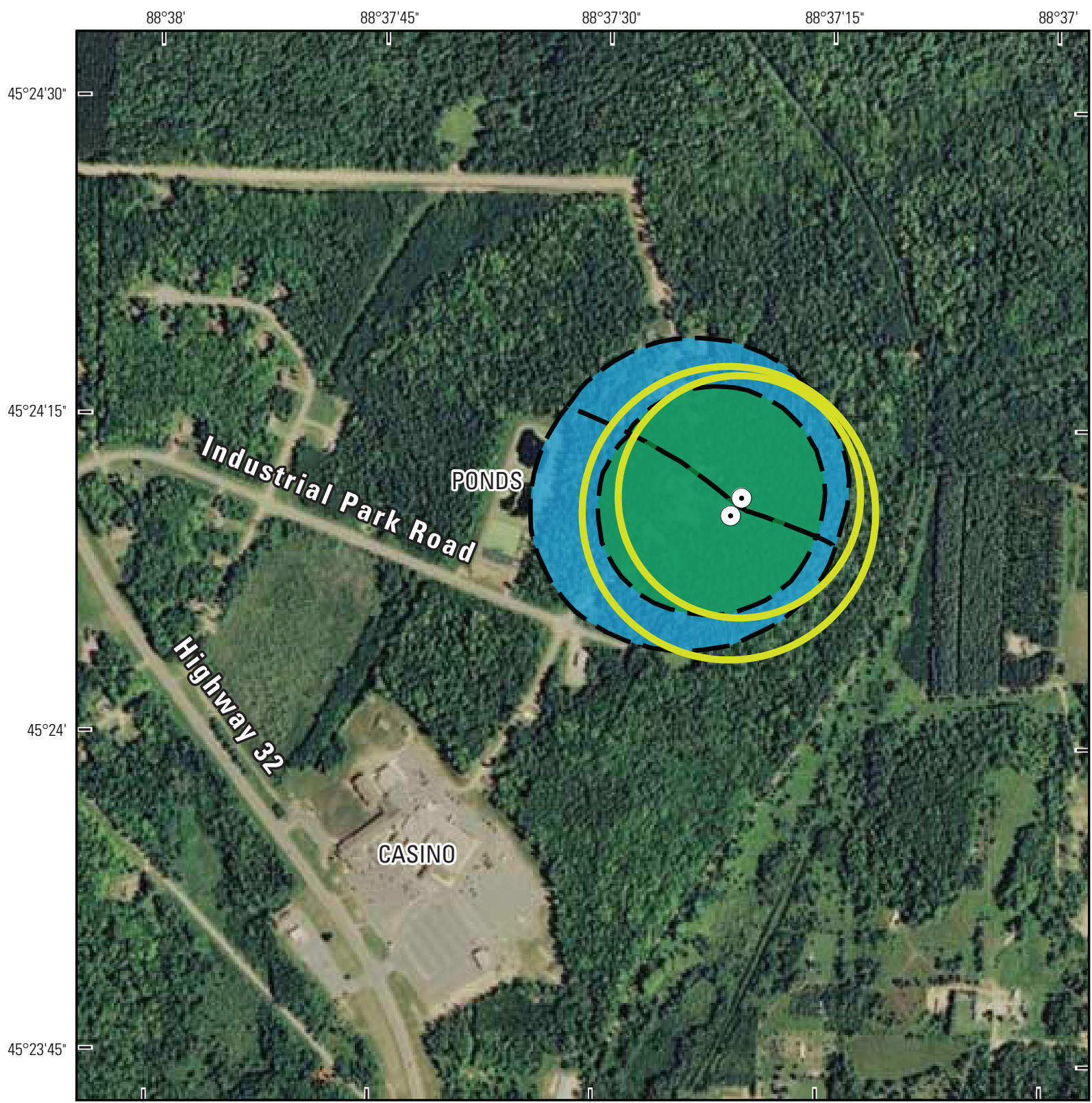

Base map from digital data sources: ESRI USA Imagery (2010)

\section{EXPLANATION}

5-year area contributing recharge (average)

10-year area contributing recharge (average)

5 -year area contributing recharge of each well, calculated by fixed radius method (Watkins, 2004)

- Pumping well

Figure 10. Map showing simulated areas contributing recharge using the GFLOW model for average pumping conditions (North well, 60 gallons per minute; South well, 88 gallons per minute) at the town of Carter, Forest County Potawatomi Community, Forest County, Wisconsin. 


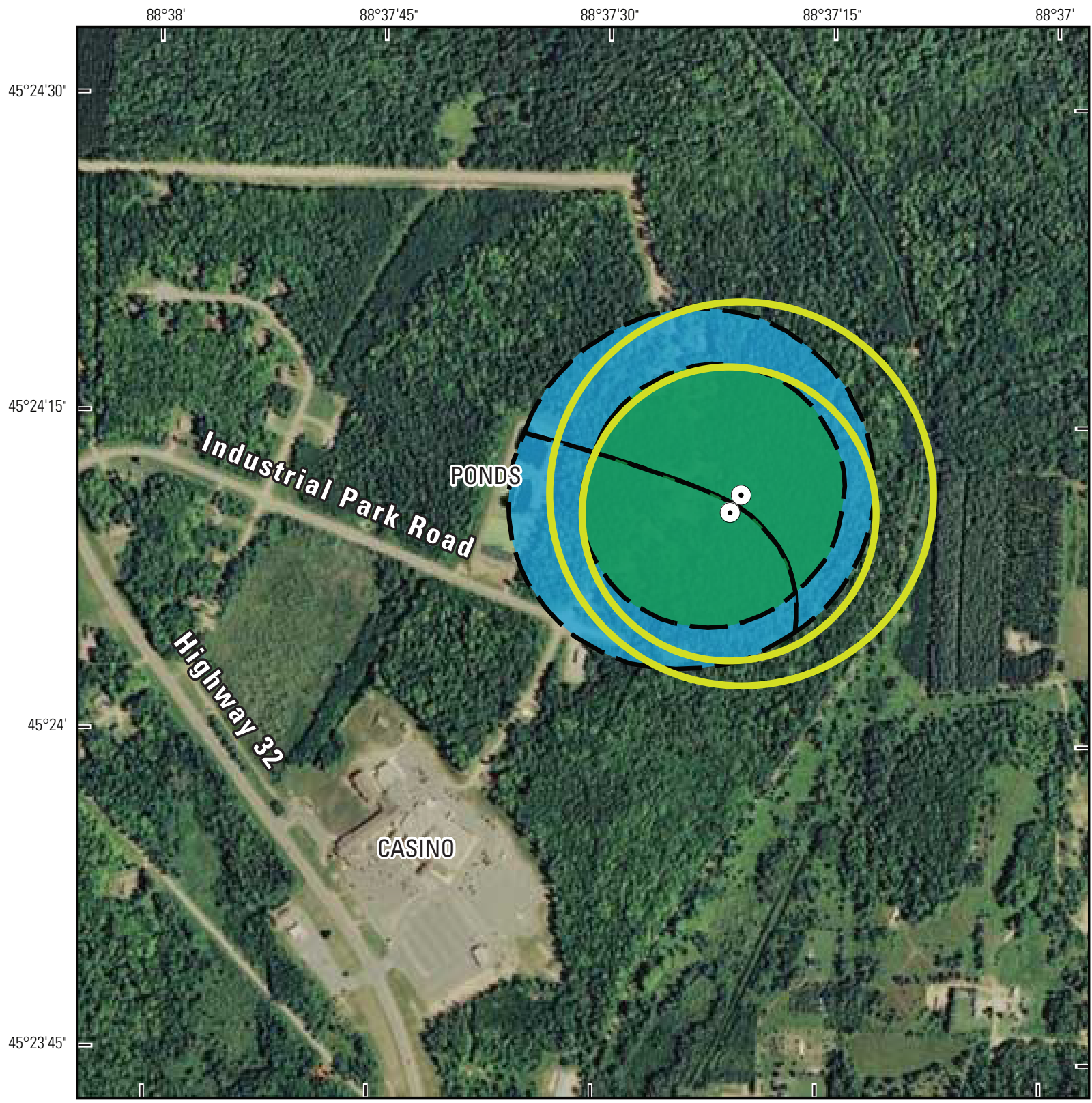

Base map from digital data sources: ESRI USA Imagery (2010)

\section{EXPLANATION}

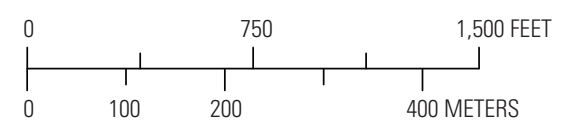

5-year area contributing recharge (average)

10-year area contributing recharge (average)

5-year area contributing recharge of each well, calculated by fixed radius method (Watkins, 2004)

- Pumping well

Figure 11. Map showing simulated areas contributing recharge using the GFLOW model for maximum pumping conditions (North well, 105 gallons per minute; South well, 88 gallons per minute) at the town of Carter, Forest County Potawatomi Community, Forest County, Wisconsin. 


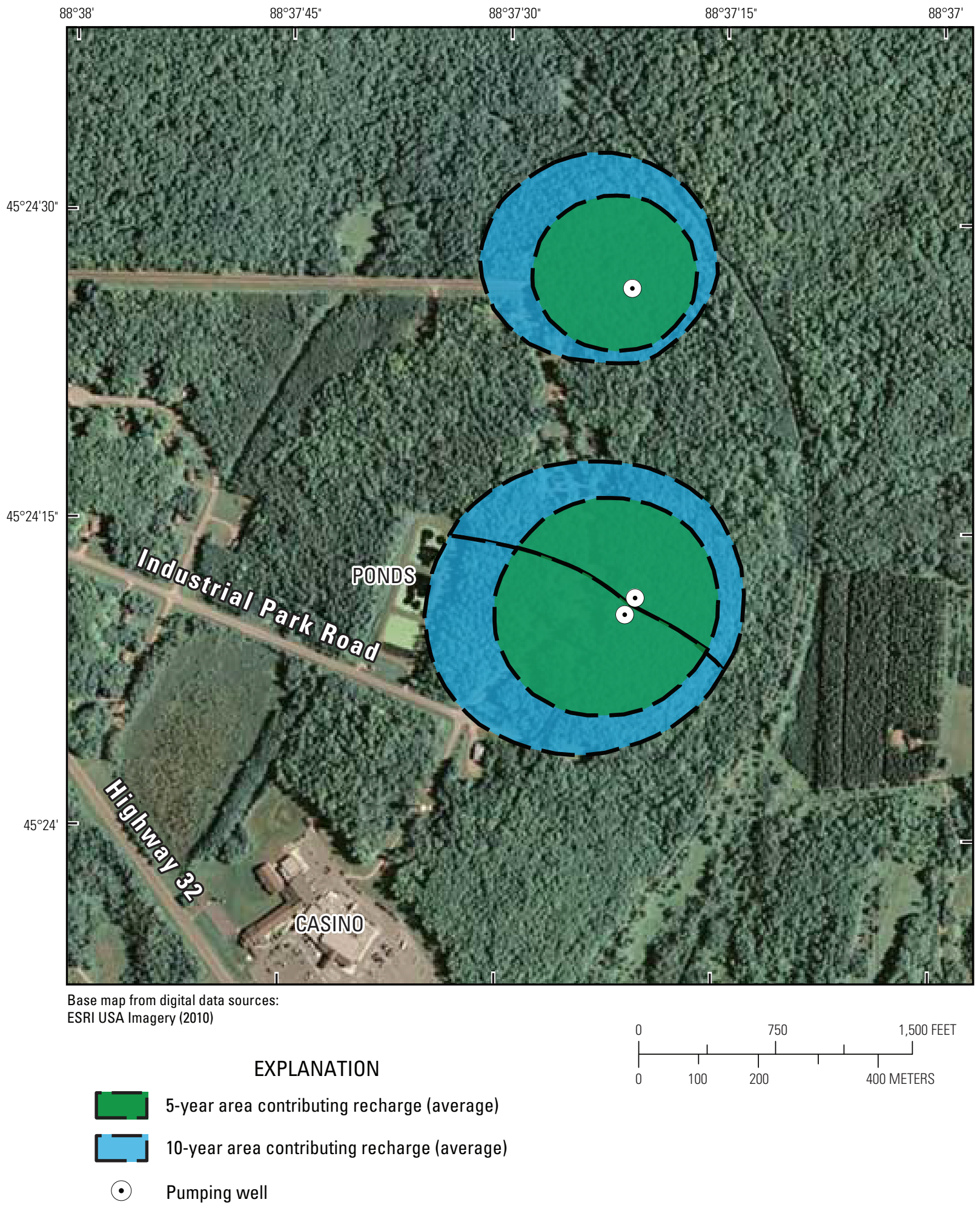

Figure 12. Map showing simulated areas contributing recharge using the GFLOW model for average pumping conditions with an additional proposed well (additional North well, 80 gallons per minute; North well, 60 gallons per minute; South well, 88 gallons per minute) at the town of Carter, Forest County Potawatomi Community, Forest County, Wisconsin. 


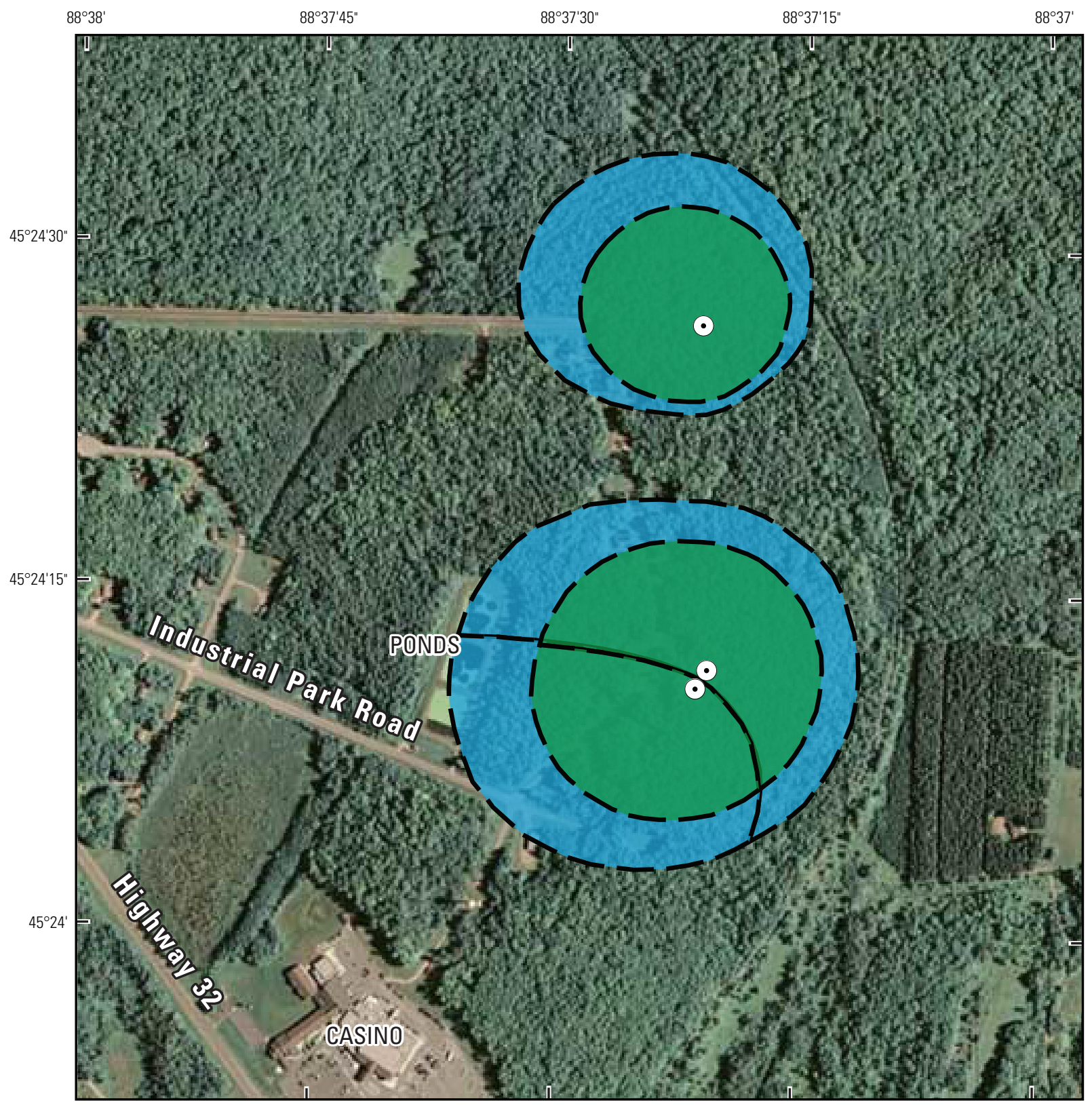

Base map from digital data sources:

ESRI USA Imagery (2010)

\section{EXPLANATION}

[ـ 5-year area contributing recharge (average)

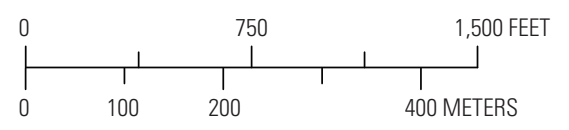

10-year area contributing recharge (average)

- Pumping well

Figure 13. Map showing simulated areas contributing recharge using the GFLOW model for maximum pumping with an additional proposed well (additional North well, 100 gallons per minute; North well, 105 gallons per minute; South well, 88 gallons per minute) at the town of Carter, Forest County Potawatomi Community, Forest County, Wisconsin. 


\section{Summary and Conclusions}

The U.S. Geological Survey (USGS), in cooperation with the Forest County Potawatomi Community (FCPC) in Forest County, Wisconsin, simulated areas contributing recharge for seven existing and three proposed wells at five locations in the shallow groundwater-flow system. The existing wells were the subject of a 2004 source-water evaluation in which areas contributing recharge were calculated using the fixed-radius method. The motivation for this project was to improve the level of detail of areas contributing recharge for the existing wells and to provide similar analysis for the proposed wells. The calculations of areas contributing recharge for the existing and proposed wells provide an estimate of the source of water to the wells.

The simulations of the shallow groundwater system in the area of interest used the framework of an existing model developed in 2002 by Kelson and coworkers. In that work, a two-dimensional, steady-state, Analytic Element Method (AEM) groundwater-flow model of the regional, shallow groundwater-flow system was developed and calibrated using the computer code, GFLOW, in conjunction with the UCODE parameter estimation program. For this study, the existing regional model was updated by including new measurements of water elevations for Lake Lucerne, Lake Wabikon, Devils Lake, and Lake Metonga (October 2010) and by expanding the areal extent of the model. A partial recalibration, focused on the newly added region of the model, was performed using the general parameter estimation software package, PEST.

The updated model was used to calculate 5- and 10-year areas contributing recharge for the 10 wells at average and maximum pumping rates. Simulated areas contributing recharge for the FCPC wells intersected surface-water features at Bug Lake and the town of Blackwell, Wisconsin. Simulated areas contributing recharge intersected ponds at the town of Carter, Wisconsin, and buildings at Devils Lake and Lois Crow Drive. In all other cases, areas contributing recharge intersected neither surface-water nor cultural features.

\section{References Cited}

Bhatt, Kailash, 1993, Uncertainty in wellhead protection area delineation due to uncertainty in aquifer parameter values: Journal of Hydrology, v. 149, no. 4, p. 1-8.

Doherty, John, 2010, PEST—Model—Independent parameter estimation, user manual (5th ed.): Brisbane, Australia, Watermark Numerical Computing, 336 p.

Fienen, M.N., Juckem, P.F., and Hunt, R.J., 2011, Simulation of the shallow groundwater-flow system near Mole Lake, Forest County, Wisconsin: U.S. Geological Survey Scientific Investigations Report 2011-5080, 9 p.
Freeze, R.A., and Cherry, J.A., 1979, Groundwater: Englewood Cliffs, N.J., Prentice-Hall, 604 p.

Haitjema, H.M., 1995, Analytic element modeling of groundwater flow: San Diego, Calif., Academic Press, 394 p.

Hunt, R.J., 2006, Ground water modeling applications using the analytic element method: Ground Water, v. 44, no. 1, p. $5-15$.

Hunt, R.J., Anderson, M.P., and Kelson, V.A., 1998, Improving a complex finite-difference ground water flow model through the use of an analytic element screening model: Ground Water, v. 36, no. 6, p. 1011-1017.

Hunt, R.J., Haitjema, H.M., Krohelski, J.T., and Feinstein, D.T., 2003, Simulating ground water-lake interactionsApproaches and insights: Ground Water, v. 41, no. 2, p. 227-237.

Hunt, R.J., and Krohelski, J.T., 1996, The application of an analytic element model to investigate groundwater-lake interactions at Pretty Lake, Wisconsin: Journal of Lake and Reservoir Management, v. 12, no. 4, p. 487-495.

Kelson, V.A., Hunt, R.J., and Haitjema, H.M., 2002, Improving a regional model using reduced complexity and parameter estimation: Ground Water, v. 40, no. 2, p. 132-143, accessed November 12, 2010, at http://onlinelibrary.wiley. com/doi/10.1111/j.1745-6584.2002.tb02498.x/abstract.

Poeter, E.P., and Hill, M.C., 1998, Documentation of UCODE, a computer code for universal inverse modeling: U.S. Geological Survey Water-Resources Investigation Report 98-4080, $116 \mathrm{p}$.

Reilly, T.E., and Pollock, D.W., 1993, Factors affecting areas contributing recharge to wells in shallow aquifers: U.S. Geological Survey Water-Supply Paper 2412, 21 p.

Soller, D.R., and Packard, P.H., 1998, Digital representation of a map showing the thickness and character of Quaternary sediments in the glaciated United States east of the Rocky Mountains: U.S. Geological Survey Data Series 38, CD-ROM.

Trotta, L.C., and Cotter, R.D., 1973, Depth to bedrock in Wisconsin: Wisconsin Geological and Natural History Survey State-wide map, scale 1:1,000,000.

U.S. Department of Agriculture, 2006, National Agriculture Imagery Program (NAIP) information sheet, accessed October 31, 2008, at http://www.fsa.usda.gov/Internet/FSA_File/ naip_final_2006_updatep.pdf.

Watkins, G., 2004, Source water assessment, Forest County Potawatomi Community, Crandon, Wisconsin: Forest County Potawatomi Community Technical Report, 7 p. 
Wisconsin Department of Natural Resources, 1995, Wisconsin Lakes: PUB-FM-800 95REV, 182 p.
Wolf, P.R., and Ghilani, C.D., 2002, Elementary surveying-An introduction to geomatics (10th ed.): Upper Saddle River, N.J., Prentice Hall, 900 p. 


\section{Appendix 1.}

The model domain from Fienen and others (2011) is reproduced here, for reference, to indicate the old model domain, which was the basis for this expanded model. 


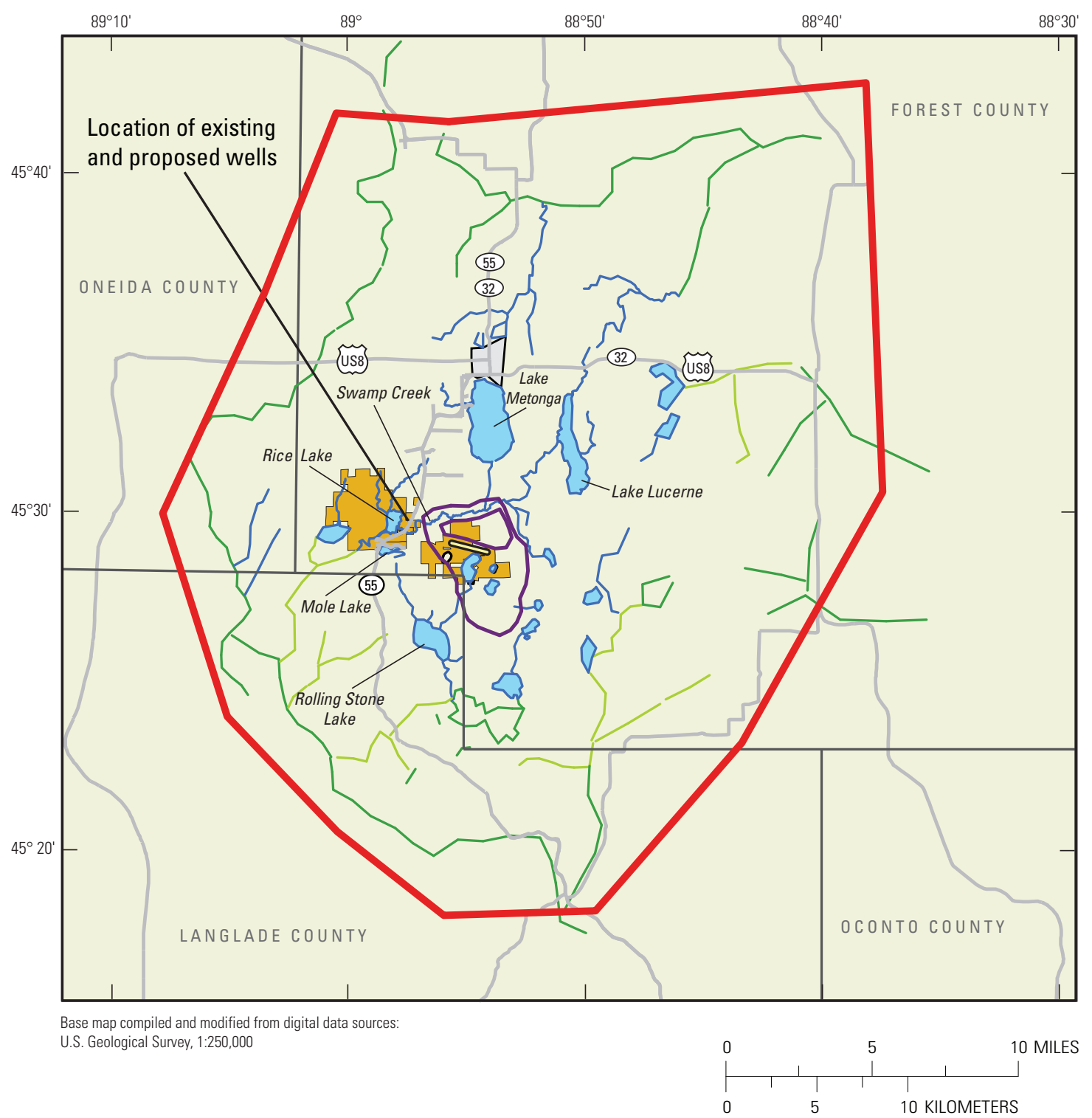

EXPLANATION
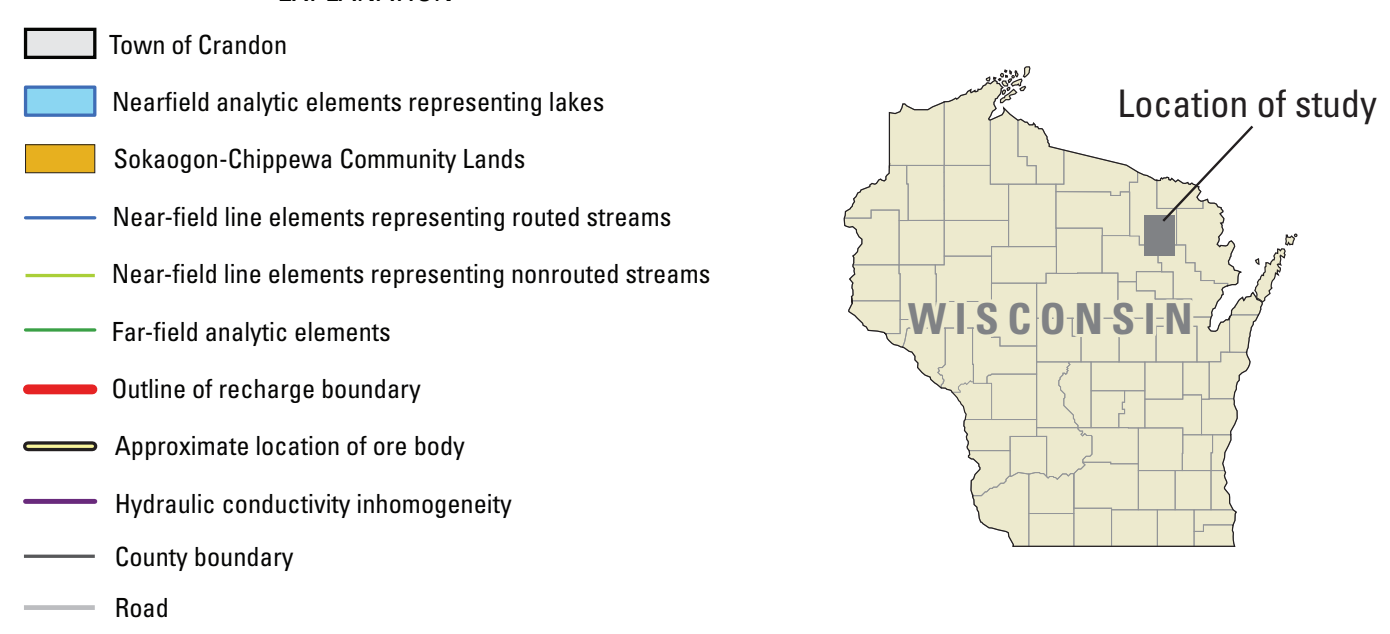

Figure 1-1. Map showing location of study area near Mole Lake, Forest County, Wisconsin, and overview of major model elements (reproduced from Fienen and others, 2011; modified from Kelson and others, 2002). 
Publishing support provided by the U.S. Geological Survey Science Publishing Network, Columbus Publishing Service Center

For more information concerning the research in this report, contact the

Director, Wisconsin Water Science Center U.S. Geological Survey

8505 Research Way

Middleton, Wisconsin 53562

http://wi.water.usgs.gov/ 


$$
\begin{aligned}
& \mathbb{8} \\
& \text { 色 }
\end{aligned}
$$

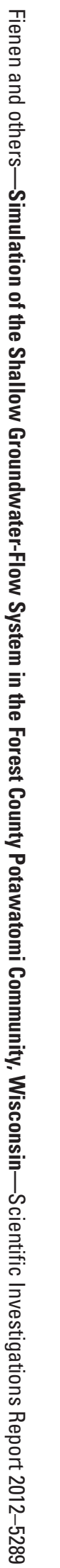

